\title{
Working
}

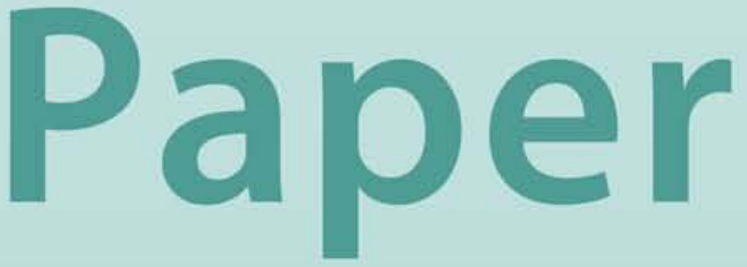


Challenges to Monetary Policy from Financial Globalization: The Case of India

Charles F. Kramer, Hélène K. Poirson, and A. Prasad 


\title{
IMF Working Paper
}

Asia and Pacific Department

\section{Challenges to Monetary Policy from Financial Globalization: The Case of India}

\author{
Prepared by Charles F. Kramer, Hélène K. Poirson, and A. Prasad \\ Authorized for distribution by Kalpana Kochhar
}

May 2008

\begin{abstract}
This Working Paper should not be reported as representing the views of the IMF.

The views expressed in this Working Paper are those of the author(s) and do not necessarily represent those of the IMF or IMF policy. Working Papers describe research in progress by the author(s) and are published to elicit comments and to further debate.

The question of how India should adapt monetary policy to ongoing financial globalization has gained prominence with the recent surge in capital inflows. This paper documents the degree to which India has become financially globalized, both in absolute terms and relative to emerging and developed countries. We find that despite a relatively low degree of openness, India's domestic monetary conditions are highly influenced by global factors. We then review the experiences of countries that have adapted to financial globalization, drawing lessons for India. While we find no strong relationship between the degree of stability in monetary conditions and the broad monetary policy regime, our findings suggest that improvements in monetary operations and communication-sometimes prompted by a shift to an IT regime-have helped stabilize broader monetary conditions. In addition, the experience of countries which used non-standard instruments suggests that room to regulate capital flows effectively through capital controls diminishes as financial integration increases.
\end{abstract}

JEL Classification Numbers:E52, F36

Keywords: capital flows, excess liquidity, financial globalization, India, liquidity management, monetary policy, monetary policy framework

Authors’ E-Mail Addresses: ckramer@imf.org, hpoirson@imf.org, and aprasad@imf.org

\footnotetext{
${ }^{1}$ The authors appreciate the very useful comments and suggestions received from Roberto Benelli, Nombulelo Duma, Lorenzo Giorgianni, Simon Gray, Roberto Guimaraes-Filho, Adarsh Kishore, Kalpana Kochhar, Scott Roger, Alessandro Zanello, M D Patra, Misa Tanaka, and other seminar participants at the Reserve Bank of India. Souvik Gupta provided outstanding research assistance.
} 
I. Introduction

II. How Financially Globalized is India?...................................................................

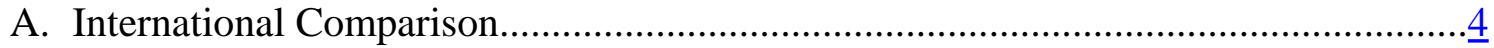

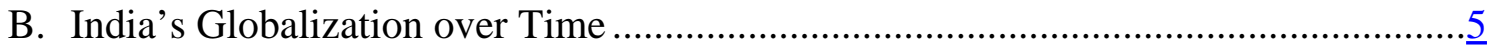

III. How Does Financial Globalization Affect the Monetary Environment?...........................

IV. Possible Policy Responses ......................................................................................

A. How Could Further Financial Globalization Affect Monetary Operations? ............... $\underline{9}$

B. How Could Further Financial Globalization Affect Monetary Strategy?..................13

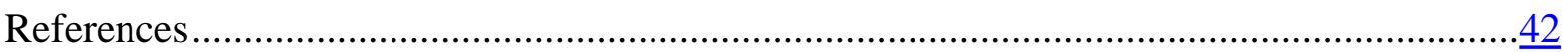

Boxes

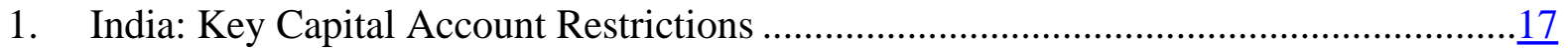

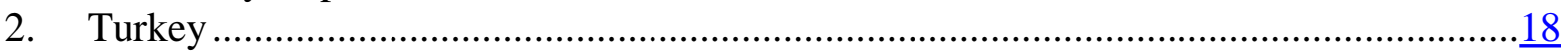

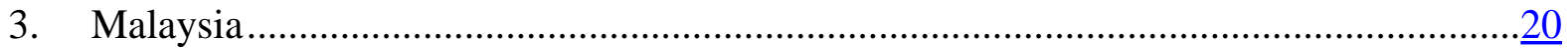

Figures

1. Measures of Financial Openness ......................................................................23

2. Measures of Capital Account Openness, 2000-05 .................................................24

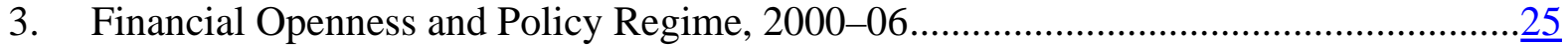

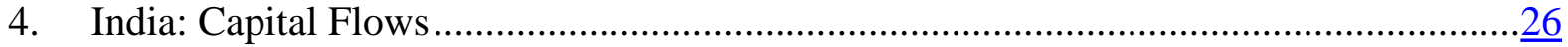

5a. India: Foreign Exchange Market ...................................................................27

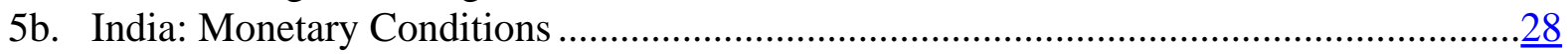

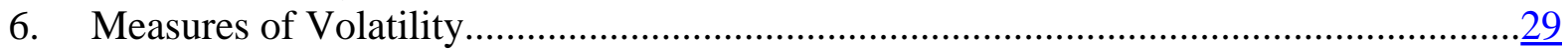

7a. Financial Operations and Exchange Rate Volatility, 2000-06 ....................................30

7b. Financial Openness and Exchange Market Pressure Index, 2000-06 ............................31

8. Financial Openness and Volatility in Monetary Conditions Index, 2000-06..................

9. Financial Openness and Volatility in Reserve Money, 2000-06..................................

10. Financial Openness and Correlation with U.S. Monetary Conditions Index, 2000-06... $\underline{34}$

11a. Policy Regime, Financial Openness, and Volatility in Monetary Conditions Index,

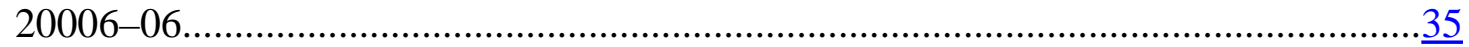

11b. Policy Regime and Foreign Exchange Market, 2000-06 ...........................................

12. Capital Flows and Central Bank Transparency, 2000-05 ...........................................

Table

1. Monetary Instruments in the Most Financially Globalized Countries ...........................22

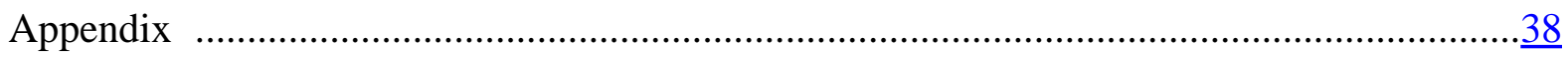




\section{INTRODUCTION}

1. How should India adapt monetary policy to ongoing financial globalization? This question has gained prominence with the recent surge in capital inflows. Predominantly as a result of that surge, India has experienced volatile monetary conditions, with rising exchange rate volatility; exchange rate appreciation; and burgeoning domestic liquidity. Efforts to manage inflows have brought out the classic tensions - the impossible trinity-among exchange rate stability, domestic monetary independence, and financial openness. So far policy has chosen from an eclectic mix of tools: some measures liberalizing inflows and others tightening; liberalizing outflows; allowing greater exchange rate flexibility, while undertaking partially sterilized intervention to smooth volatility; and hiking policy interest rates and the reserve ratio.

2. Looking to the experiences of the emerging and developed countries that are more financially globalized, the paper asks, what can India expect in terms of the evolution of its own monetary conditions as financial globalization proceeds? And how would the monetary framework need to evolve as India becomes still more integrated with the global financial system?

3. To briefly summarize the conclusions, this chapter finds that, although the most financially globalized countries tend to experience more volatile capital flows, they do not necessarily experience more volatility in monetary conditions, monetary aggregates or exchange rates. This suggests that the most globalized countries have adapted their policy regimes to keep capital flows from creating volatility in monetary conditions. In particular, as capital account restrictions are lifted, countries appear to shift to more flexible exchange rate regimes. However, we find no clear association between the policy regime at a broad level-e.g., inflation targeting versus more eclectic monetary regimes, exchange rate pegs versus floats - and the degree of stability in monetary conditions. While countries with independent floats and inflation targeting seem to experience less exchange market pressure, the result does not hold if a broader index of monetary conditions (including domestic interest rate changes) is used. We then explore some subtler elements of the monetary framework, namely operations and communications, that may hold the key to effective monetary management of financial globalization.

4. The paper proceeds as follows. Section II compares the degree of financial openness in India to a range of other countries, and also looks at how its openness is changing recently. Section III examines how financial globalization tends to affect the monetary environment, and Section IV draws some policy implications.

\section{How FinANCIALLY GLOBALIZED IS INDIA?}

5. This section documents the major trends in the evolution of the international financial integration of India. To do so, we first study the international balance sheet of 
India. We then examine flow data, including to assess the pace at which India is integrating. For a third perspective, we also examine measures of market depth, e.g. foreign exchange turnover, and market pressure.

\section{A. International Comparison}

6. The sample covers a broad range of industrialized and emerging countries, including a few financial centers (e.g., Hong Kong). All variables used as proxies for financial openness are normalized by GDP, as the impact of openness on monetary conditions is likely to depend on the size of capital flows in relation to GDP (see the Data Appendix for details). ${ }^{2}$

\section{India is not very financially globalized, in a stock sense, but is fast globalizing by} opening its economy to capital inflows. The total of foreign assets and liabilities is the lowest in the sample (Figure 1). Using a flow-based measure (the sum of capital inflows and outflows, in absolute terms) yields broadly the same result. This is because capital outflows in India have averaged less than 0.4 percent of GDP since the beginning of the decade (the lowest value in the sample). In contrast, capital inflows are now close to 5 percent of GDP, comparable to the levels seen in other large emerging countries (Brazil, China), although well below that in the major financial centers.

\section{India's low financial openness in part reflects the restrictions in place on cross-} border capital transactions. (Figure 2 and Box 1). The top panel of Figure 2 shows a summary measure of capital account restrictions (the Abiad-Detragiache-Tressel index). By this measure, India's capital account is more open than those of China, Thailand, or Brazil, but less so than those of Korea, Turkey, or Mexico. The bottom panel uses a broader liberalization measure (the Chinn-Ito index) which incorporates information on current account restrictions, presence of multiple exchange rates, and requirement of the surrender of export proceeds. ${ }^{4}$ On this measure, India is one of the least open in the sample, along with

\footnotetext{
${ }^{2}$ Normalizing the ratios by financial market size (measured as the sum of bank assets, private and public debt securities, and stock market capitalization) would reduce the variation across countries in level of financial globalization but otherwise yield qualitatively similar results: for gross capital flows (respectively, inflows), the correlation of the ratios normalized by GDP and normalized by capital market size are 0.7 and 0.8 , respectively, for the subsample of countries for which financial market size data are available.

${ }^{3}$ In Figure 2 and successive charts that show countries on the $\mathrm{x}$-axis, countries are ranked from highest to lowest in terms of their financial openness, measured as gross assets plus liabilities over GDP.

${ }^{4}$ See Chinn and Ito (2007) for details on the calculation of the index.
} 
China, Turkey, and South Africa. However, Kramer and Kohli (2007) cite evidence that India is more financially open on a de-facto basis than is suggested by de jure regulations. ${ }^{5}$

9. Being a relatively less open country results in India experiencing relatively low volatility in capital flows, similar to other less open emerging countries. In contrast, the financial centers in the sample (Hong Kong, United Kingdom, Singapore) are characterized by both high and volatile capital flows (Figure 3).

\section{B. India's Globalization over Time}

10. Figure $\mathbf{4}$ shows that total net capital flows have risen about sixfold since the first quarter of 2004. This partly reflects the pick-up in foreign institutional investment (FII) inflows since 2003/04. Since 2004/05, the volatility of FII inflows-as measured by the 12-month moving standard deviation in monthly inflows-has also risen notably. The past two years have seen other types of inflows, such as external commercial borrowings (ECBs), accelerating as well, liberalization of ECB restrictions allowed Indian companies greater access to foreign financing. More recently, FDI inflows have also surged.

\section{Another indicator of India's growing financial integration is the depth of the} foreign exchange market. Turnover has risen over time, especially since the second half of 2002, and this trend has been accompanied by an increase in volatility (Figure 5a). Data from the BIS Triennial Survey, which includes forwards and swaps, show an even more dramatic rise in daily turnover from \$7 billion to \$34 billion since 2004 (Kramer and Kohli, 2007).

12. At the same time, there has been a marked increase in the volatility of daily movements in the rupee vis-à-vis the U.S. dollar. India's exchange rate volatility, by this measure, is now almost at par with that of Mexico (which experienced a similar average level of capital inflows to GDP during 2000-06), although still lower than that of South Africa (which experienced nearly twice as much inflows to GDP during the same period). Similarly, exchange market pressure (measured by the sum of rupee appreciation and change in foreign exchange reserves normalized by reserve money) has increased (Figure 5a). A broader market pressure index (measured by the weighted sum of foreign exchange purchases and Reserve Bank of India (RBI) sterilization operations through overnight repos and market sterilization bonds, normalized by reserve money) shows that market pressure has risen sharply in the second half of 2007, coinciding with the surge in inflows since July and more volatile monetary conditions (measured by the past 12-month standard deviation of a broad monetary conditions index calculated as the weighted average of domestic interest rates and

\footnotetext{
${ }^{5}$ Also, Pasricha (2007) finds that India’s de-facto openness is much higher than its de-jure controls would suggest.
} 
real effective exchange rate movement, with weights of 0.8 and 0.2 , respectively) (Figure 5b). ${ }^{6}$

\section{How Does Financial Globalization AfFect the Monetary EnVironment?}

13. This section uses international comparisons to examine whether increased financial openness is associated with higher volatility in the monetary environment. We use several indicators of the latter, including exchange rate volatility and exchange market pressure (EMP), volatility in a monetary conditions index (MCI), and volatility in reserve money.

\section{Currency market volatility appears moderate in India compared to most of} the more financially open countries. The average EMP over 2000-06 is lower in India compared to more financially open emerging countries with managed floats like Malaysia or Russia (Figure 6). Exchange rate volatility has risen, as noted earlier, but remains one of the lowest in the sample. This suggests that India's capital account restrictions help insulate it to some degree from exchange rate pressures faced by more financially open countries. That said, Figure 7a shows that the correlation between financial openness and exchange rate volatility is weak (in fact, negative in our sample); some of the most financially globalized countries have very modest levels of exchange rate volatility (perhaps reflecting deep and liquid currency markets). The correlation between financial openness and EMP is also weak (Figure 7b).

\section{Similar results are found examining measures of volatility in monetary}

conditions. Figure 6 shows that monetary conditions (measured by an MCI index) tend to be less volatile in India than in some of the more financially open emerging countries in our sample (South Africa, Chile, and Russia). ${ }^{7}$ At the same time, other financially globalized emerging countries (Thailand, Malaysia) and most of the advanced countries also exhibit low MCI volatility. In fact, the correlation of MCI volatility with financial openness in our sample is negative (Figure 8). Using the volatility of reserve money (normalized by GDP) as an alternative measure yields similar results (Figures 6 and 9), showing that financial openness is not closely related to this measure of volatility.

\footnotetext{
${ }^{6}$ For the market pressure index, we also use weights of 0.8 and 0.2 for the domestic and external component, respectively. Using an alternative measure with equal weights yields qualitatively similar results (see footnote 7).

${ }^{7}$ In the case of India, Kannan, et al (2006) find that the interest rate is more important than the exchange rate in influencing monetary conditions, when accounting for the credit stance. However, for some countries in the sample (e.g., Malaysia), the exchange rate tends to exert equal importance. We therefore also used an alternative measure of MCI with weights of 0.5 and 0.5 . Our results remain qualitatively unchanged.
} 
16. Next, we examine another dimension of financial globalization, i.e., the comovement between monetary conditions in financially integrated countries. Specifically, we investigate how the monetary environment in the United States affects the monetary environment in our sample countries. More financially open countries appear to exhibit a higher correlation of their MCI with the U.S. MCI (Figure 10). ${ }^{8}$ But the relationship is statistically weak, with significant outliers on both sides. For example, India's MCI has a coefficient of correlation of 0.7 with the U.S. MCI. ${ }^{9}$ This level of correlation is comparable to that of other more financially globalized Asian countries (Thailand, Malaysia and Singapore), despite India’s relatively closed capital account.

17. The question is then how the most financially open countries design the monetary framework to maintain monetary stability in the face of greater openness, greater correlation with U.S. monetary conditions, and more volatile capital flows. The obvious conjecture would be that a particular policy regime helps them stabilize monetary conditions in the face of more volatile flows. For example, economies that become more open to international financial markets may shift to more flexible exchange rate regimes to reduce their vulnerability to shocks (Hussain, Mody, and Rogoff, 2005). It could also be the case that one type of regime or another can successfully "import” the relative stability of U.S. monetary conditions.

18. Empirically, do countries tend to adopt particular policy regimes as they gain greater access to international financial markets? Using a de jure measure such as the Chinn-Ito index (Figure 11a, bottom panel), there is a clear association between capital account liberalization and the choice of a flexible exchange rate regime, confirming results in Hussain, Mody and Rogoff (2005). However, using either de jure or flow-based measures of financial openness, we find no evidence that the more financially open countries in our sample prefer a particular type of monetary policy framework (Figure 11a, top panel).

19. The choice of monetary policy framework in turn seems to have little influence on the volatility in monetary conditions in our sample, when the latter is measured using MCI volatility. Figure 11a (top panel) shows that MCI volatility has been low in most countries in our sample (except Turkey) over 2000-06, whether they were inflation targeters, anchored monetary policy to the exchange rate or, as in India, have a multiple objective ${ }^{10}$ or other type of monetary policy framework in place.

\footnotetext{
${ }^{8}$ However, we find that the correlation coefficient is negative (higher than 0.5 ) for the sub-sample of countries with lower levels of financial openness.

${ }^{9}$ Appendix I shows the correlation coefficient between U.S. and domestic monetary conditions and financial openness for other countries in the sample.

${ }^{10}$ Including for example full employment and low exchange rate volatility, in addition to inflation.
} 
20. The choice of exchange rate regime does not seem to relate strongly either to the volatility of domestic monetary conditions. Most countries with pegs or managed floats experienced below-average MCI volatility (Figure 11a). Similarly, volatility levels for countries with flexible exchange rate regimes are broadly evenly distributed above and below the sample average.

21. The broad policy regime choice seems to matter a bit more, when financial globalization-induced volatility is defined more narrowly as exchange market volatility (measured using an EMP index). Figure 11b shows that while some countries in our sample with IT regimes have experienced higher-than-average exchange rate volatility over the period 2000-06, they have intervened less and generally experienced below-average EMP. Flexible exchange rate countries exhibit a similar pattern to IT countries. However, the correlation remains weak. Several countries (including India) with non-IT regimes and managed floats (or a fixed exchange rate in the case of Hong Kong SAR) have also experienced low levels of EMP over the same period.

\section{Possible Policy Responses}

22. Two trends are evident in the Indian data on financial flows and monetary conditions analyzed in the previous sections: (1) an increase in the size and volatility of all types of inflows; and (2) a relatively high degree of co-movement in India's monetary conditions index with that of the United States, notwithstanding India's low financial openness. Both of these stylized facts are consistent with the experiences of countries in our panel.

23. However, the data also suggest that looking across the range of countries, greater financial openness is not associated with higher volatility in monetary conditions. This result does not seem to reflect solely the choice of a broad policy regime by countries as they become increasingly financially globalized. Our findings confirm that countries tend to shift to more flexible exchange rate regimes as capital account restrictions are lifted; we also find that IT and freely floating countries have experienced lower-thanaverage exchange market pressure; however, we find no strong relationship between the degree of stability in monetary conditions-using a broader MCI index-and the choice of a particular exchange rate or monetary regime.

24. Success in maintaining monetary stability in the face of financial globalization thus must have to do with more subtle elements of the monetary framework —ones such as operations and strategy. The next section focuses on the implications of these stylized facts for monetary operations and monetary policy strategy, drawing on other countries' experiences. While it is difficult to predict whether India will face similar difficulties, there are lessons that can be drawn from reviewing the experiences of countries that have dealt with such volatilities. 


\section{A. How Could Further Financial Globalization Affect Monetary Operations?}

\section{Greater financial globalization has helped deepen markets, which in turn} encourages and supports a convergence of monetary policy operating procedures to market-based instruments. ${ }^{11}$ In other words, with some exceptions, the central banks may have moved away from direct quantitative interventions (using blunt instruments like the reserve ratio) that make the guiding principles and impacts of monetary policy less clear, to more forward-looking interest rate management that send clearer signals through the financial markets channel. This, together with a freer exchange rate, may allow better control of domestic monetary conditions (short-term interest rates) as countries open up financially (Stevens, 2006). In the rest of the section, we argue that, in addition to deeper markets, two elements of monetary operations—liquidity forecasting and liquidity management—are key to countries' effective monetary management of financial globalization. We also discuss countries' experiences using capital controls and other non-standard instruments.

\section{Liquidity forecasting}

\section{Financial globalization makes it more difficult to forecast capital flows, in light of rising volatility in flows (measured by the standard deviation). Under normal conditions, central banks can detect seasonal patterns, and impose these on underlying trends in demand, to obtain a monthly forecast for net foreign exchange demand. However, strong exchange rate pressure makes it impossible to predict future purchases or sales accurately (Gray, 2007). This can result in higher exchange rate volatility in countries that use interest rates as a tactical target, or contribute to more short-term volatility in liquidity conditions in countries which target the exchange rate. ${ }^{12}$ In both cases, a more open financial environment implies that central banks may need to upgrade their ability to forecast foreign exchange flows.}

27. Strong competitive economies where capital inflows are vibrant face a particular challenge for liquidity management. The liberalization of the capital account can lead to continued inflows of foreign exchange and accumulation of net foreign assets by the central bank, even under a genuine free floating rate. In some countries, this can be consistent with an objective to build-up international reserves for precautionary motives, e.g., to reduce external vulnerability. However, the country can face a point where the cost of holding additional reserves may exceed the benefits. It may then need to adopt a policy to control

\footnotetext{
${ }^{11}$ See International Monetary Fund (2005) and Hawkins (2005).

${ }^{12}$ If the central bank has an exchange rate target, it will have little control over foreign exchange transactions at least in the short term (volumes will be determined by the market) and may be unable to forecast them accurately. This in turn can undermine control of the central bank over liquidity conditions. If in contrast the central bank uses a tactical interest rate target, and foreign exchange interventions are not expected to influence the exchange rate, the volume is likely to be more controllable by the central bank (see Stevens, 2006, for Australia's experience pre- and post-floating the exchange rate).
} 
reserve accumulation. Mexico, for example, has adopted in May 2003 such a policy (see Williams, 2005, and Sidaoui, 2005).$^{13}$ The policy is automatic and aimed solely at slowing the pace of accumulation: the authorities neither adopted a target, nor defined an optimal level for foreign reserves. Each quarter, the central bank supplies back to the market in equal daily installments half of what its previous quarter purchases. Because the policy is clear and pre-announced, it does not impact the market exchange rate. ${ }^{14}$

\section{Proactive liquidity management}

\section{As noted earlier, a common policy response of countries facing large capital} flows due to financial globalization has been to intervene in foreign exchange markets to mitigate volatility and appreciation pressures. However, such intervention by the central bank can undermine the effectiveness of monetary policy procedures, if the resulting surplus liquidity is not actively managed. Most central banks (including India's) have now shifted to market-based instruments, or a mix of quantitative and market-based instruments to carry out their sterilization objectives. While standing facilities (SFs) - used at the initiative of individual banks - are the preferred market instrument in some countries, most central banks (including in India) now use direct open market operations (OMOs) or deposit facilities (DFs) either as their main instrument or in support of SFs and quantitative instruments (such as reserve requirements). Because OMOs/DFs are used at the initiative of the central bank, they can be calibrated in view of the central bank's liquidity forecast to support its operating target (generally a short-term interest rate, but in some cases money, or a bank reserves target, e.g., the “corto” or short position in Mexico).

\section{A key operational constraint on the conduct of monetary policy in the face of} large inflows is therefore the availability of domestic sterilization debt instruments, with a broad range of maturities to allow both "fine-tuning” (dealing with short-term volatility in liquidity conditions) and sterilization of more durable inflows. The experience of Malaysia in the early 1990s underscores the need for a large "war chest" of securities for open market operations (Box 3). In some countries, the central bank is able to use government securities as sterilization instruments, with some constraints (such as, in India, the annual ceiling on debt issuance set by the fiscal responsibility law). This option avoids the risk of segmenting the market for risk-free bonds by issuing central bank paper, resulting in distorsions of the

\footnotetext{
${ }^{13}$ For details on operation of the policy, see: http://www.banxico.org.mx/portalesEspecializados/tiposCambio/didactico/mecanismo_red_acum_reservas.html. Such operations should be grouped with monetary operations in the liquidity forecast (Gray, 2007).

${ }^{14}$ The peso foreign market is sufficiently deep to absorb daily operations (prior to introducing the floating exchange rate, the Bank of Mexico removed all the restrictions imposed in preceding years and encouraged the development of derivatives markets. As a result, daily trading volumes increased 10 -fold since 1995). In shallower markets, auctions could be conducted weekly or at a lower frequency. (Relatedly, Turkey engages in preannounced operations to augment its foreign exchange reserves; see Box 2.)
} 
yield curve (Saggar, 2007). However, some central banks (e.g., Mexico in 2000) eventually started issuing their own securities when it became obvious that commercial banks were holding too much long-term government paper as a result of the sterilization process (Sidaoui, 2005).

\section{As greater financial globalization puts a premium on active liquidity} management by the central bank, a case can be made for shifting to a predominantly open market or "active" approach (also called "Fed" or "hands on" style). Such an approach assigns a smaller role to changes in reserve requirements and SFs, while involving frequent market operations. ${ }^{15}$ For example, in the United Kingdom, reserve holdings have become entirely voluntary (Table 1). In countries with well developed money markets, SFs can still be operated in support of OMOs, to limit the volatility of the overnight inter-bank rate and provide a "safety valve" for individual banks (Hawkins, 2005). But the ability of the central bank to conduct frequent and flexible OMOs will ultimately determine the effectiveness of liquidity management, as measured by the degree of central bank control over short-term interest rates:

- $\quad$ First, increased market depth associated with financial globalization increases the effectiveness of OMOs, which (in a virtuous cycle) can in turn contribute to further financial market development by increasing market liquidity.

- $\quad$ Second, the open market approach, where the policy rate is set somewhere below the rate of the marginal (repo) lending facility and above the deposit facility (reverse repo) rate, would allow the central bank to more clearly signal its policy stance, especially when the economy faces a structural liquidity surplus (e.g., due to continuing inflows). In this case, the structural surplus of the banking system weakens the transmission of policy rate changes to other market rates. In India for example, notwithstanding three consecutive 25 bps hikes in the repo (lending rate) and four increases in the cash reserve ratio totaling 200 bps, yields on government securities have only gone up by $30-40$ bps over the past year. ${ }^{16}$

\section{Shifting to an open market approach would require the use of debt or deposit} sterilization instruments by the central bank with a wide range of maturities (both shortterm-1-2 weeks—and longer-term—91-day to 1 year). For example, Turkey has recently moved to issue paper of maturity up to 91 days, and introduced deposit facilities to better

\footnotetext{
${ }^{15}$ The frequency at which OMOs are conducted can vary from daily (Monetary Authority of Singapore) to weekly (ECB and Bank of England, where the presence of SFs and full reserve averaging lessens the need for daily OMOs). See Table 1. Central banks can also conduct exceptional fine-tuning operations in periods of financial turmoil.

${ }^{16}$ Lending rates, as indicated by the prime lending rate, and deposit rates have been raised, but some banks appear to be reversing this recently in the absence of further policy signals from the RBI.
} 
control short-term liquidity (Box 2). The RBI already uses longer-term instruments (MSBs) in addition to reserve requirements to sterilize the structural liquidity surplus. However, so far, it has relied on its overnight operations through the Liquidity Adjustment Facility to curb short-term volatility in liquidity conditions. Completing the shift to an open market approach in the context of India would involve the use of a full range of instruments, including shortterm instruments (through the introduction of regular deposit auctions or the issuance of government securities with 1-2 week maturities) to conduct fine-tuning operations, in addition to regular issuance of long-term OMOs.

\section{Foreign currency swaps are other instruments that central banks can use to} sterilize the liquidity impact of their foreign exchange intervention. ${ }^{17}$ However, they do not promote the development of capital markets in the same way as central bank participation in the bond or money markets. Moreover, their cost should be identical to that of OMOs using central bank paper if conducted at market rates.

33. Empirically, Table 1 confirms that the most financially globalized countries in our sample tend to have an "active" approach, involving frequent and flexible use of OMOs (for example, weekly repos, circa 1-week maturity, in the United Kingdom, combined with overnight fine-tuning operations, and longer-term monthly repos). Most also operate SFs, in support of OMOs. India's recent move to step-up the frequency of OMOs suggests that the RBI is increasingly moving toward an "active" approach to liquidity management (in line with the policy statements issued since late 2006).

\section{Other measures: capital controls and liberalization of outflows}

34. As foreign exchange market interventions can become costly and may only be effective in the short term (see Edison, et al, 2007), some central banks have also applied non-standard instruments to manage inflows and/or moderate the pace of reserve accumulation. India, for instance, recently imposed restrictions on ECBs and issuance of offshore equity derivatives. Other countries have also adopted different capital control policies on limiting inflows. Malaysia in 1994 imposed temporary controls on short-term inflows (Box 3). Thailand in late 2006 imposed an unremunerated reserve requirement to fend off speculative inflows.

35. In some cases, controls were generally subsequently relaxed, and accompanied by measures to further liberalize inflows (Malaysia) and outflows (Malaysia and Thailand). Several Asian countries (Korea, China, Taiwan) have recently raised the limits on national pension funds' and insurers' investments abroad, while others have provided greater

\footnotetext{
${ }^{17} \mathrm{FX}$ swaps are used by a number of central banks and should not affect the underlying exposure of the market to foreign exchange. They should therefore be grouped with monetary operations in the liquidity forecast (Gray, 2007).
} 
flexibility to licensed onshore banks to undertake foreign currency business (Malaysia) and allowed residents to increase foreign currency borrowing and invest more in foreign currency assets (Malaysia, Korea). Similarly, India has recently increased limits on individual, corporate, and institutional investments abroad.

36. The response of selected European countries ${ }^{18}$ to capital inflows also involved nonstandard instruments (Otker-Robe, et al, 2007). Between 1994-2005, these countries received gross flows averaging about 9.6 percent of GDP. Sterilized intervention and exchange rate changes (widened exchange rate bands or switch to floating exchange rate regime) were a common response in many countries. Capital controls were also imposed on short-term inflows (Bulgaria, Hungary, Poland). In addition, Bulgaria and Czech Republic liberalized outflows.

37. The experiences of the European countries however suggest that as countries become more integrated with international financial markets, there is little room to regulate capital flows effectively (Cardarelli, et al, 2007, find a similar result for a wider range of countries). The most effective ways to deal with capital inflows include deepening the financial markets, strengthening financial system supervision and regulation, where needed, and improving the capacity to design and implement sound macroeconomic and financial sector policies (Otker-Robe, et al, 2007). In the following section, we discuss measures that more financially open countries have taken to upgrade their monetary policy strategy.

\section{B. How Could Further Financial Globalization Affect Monetary Strategy?}

\section{Increased uncertainty}

38. Financial globalization makes it harder to read the medium-term inflation outlook due to greater exposure of asset prices to foreign shocks/spillovers, and their long-term implications for price stability. Strategies that attribute a prominent role to the analysis of monetary aggregates are challenged by financial globalization. Cross-border financial flows (portfolio investments and mergers and acquisitions activity of non-financial corporations) for instance, are genuine elements of globalization, which can account for changes in net foreign assets and money. Despite their likely remote direct effects on consumer prices, these transactions cannot be simply be netted out when analyzing the external sources of money growth. Rather, they have to be analyzed with respect to their likely impact on residents' income and on asset prices (to assess potential wealth effects). The repercussions for price stability could take place over a number of years. This possibility implies that monetary policy in a financially globalized economy may need to place

\footnotetext{
${ }^{18}$ Bulgaria, Croatia, the Czech Republic, Estonia, Hungary, Israel, Latvia, Lithuania, Poland, Romania, and Turkey.
} 
increased emphasis on preserving price stability over a longer time horizon, extending beyond the medium term. The analysis may also need to factor in the potential repercussions of developments in monetary liquidity on output volatility and price stability (Papademos, 2007).

\section{Changes in the monetary transmission mechanism}

39. As domestic asset prices are increasingly determined by global factors, the channels of transmission of monetary policy might change as well. In particular, domestic interest rates could be increasingly influenced by global factors. This is borne out by the evidence in our sample, which showed increasing co-movement of countries' MCI with that of the United States as they became more financially globalized. This suggests that monetary policy makers must pay increased attention to conditions abroad as well as at home.

40. Does this imply that financial globalization significantly reduces the influence of central banks on monetary conditions and thereby makes monetary policy less effective? Even if the relative importance of the different monetary transmission channels might be affected by the ongoing financial globalization, in theory a central bank is still able to preserve price stability under an open capital account under a floating exchange rate. In fact, the Mundell-Fleming model implies that monetary policy becomes more effective under a floating exchange rate regime, the higher the degree of capital mobility (Weber, 2007); the exchange rate channel more than offsets the weakening of the interest rate channel.

41. Central banks can also retain considerable leverage over short-term and, to a lesser extent, long-term rates even in financially integrated economies (Bernanke, 2007). Through active liquidity management (as discussed in the previous section), the central bank can drain any surplus liquidity in the inter-bank markets to keep interest rates close to the policy rate (or within a policy corridor). This gives the central bank the ability to control to a large extent short-term nominal rates (and therefore real rates if inflation is sticky in the short run).

42. Central banks also retain a degree of control over long-term interest rates, through clear communication to set market expectations. By shaping expectations about short-term nominal rates, central banks can influence long-term rates (which can be viewed as the weighted average sum of expected future short-term rates plus a term premium). If the central bank is also able to anchor inflation expectations, by employing consistent and predictable policies, this in turn gives the bank control over long-term real rates. The following section elaborates on the increased role of central banks' transparency policies and communication in helping shape markets' views and sharpen monetary policy effectiveness in a financially open economy. 


\section{Communication and transparency}

43. The increased uncertainty and the changes in monetary transmission associated with financial globalization underscore the importance of a central bank's effective and consistent communication. Stepped-up communication with market participants is especially important when globalization implies a greater share of foreign investors that may be less well informed about domestic economic conditions-or alternatively, are used to the communication modalities used in large developed countries. Several emerging countries, sometimes prompted by a shift to an IT regime, have emphasized clear and frequent communication in the new framework, contributing to a general trend toward increased transparency (see Chapter III of IMF Country Report No. 08/52). For example, Turkey’s central bank presents a quarterly analysis of risks to price stability and issues summary reports of the monetary policy committee's views on the inflation outlook within 5 days of policy meetings (Box 2).

44. Financial globalization can also alter the response of markets to monetary policy in unexpected ways, putting a premium on clear and frequent guidance by the central bank. For instance, an interest reduction aimed at slowing inflows may on the contrary accelerate them if investors take it as a sign that domestically-financed investment will pick up. Similarly, greater liberalization through the easing of restriction on outflows can encourage more capital inflows, as it reduces the cost of exit. In such instances, monetary policy's ability to deal with the volatility of capital inflows depends on the central bank's credibility in guiding private-sector expectations. Moreover, policy objectives must be mutually consistent. Inconsistent objectives lead to periodic shifts in policy priorities, adding to uncertainty and noise in financial markets, undermining policy credibility, and making the process of policy formulation more susceptible to lobbying by special interests.

45. Greater transparency of monetary policy also encompasses the need to explain the role of different monetary instruments, and the circumstances under which different instruments might be used. There could be a trade-off between a monetary framework with fewer instruments, which would promote simplicity and make it easier to predict what any policy moves would accomplish, and one with a broader range of instruments e.g., for fine-tuning. In either case, it is important that the central bank clearly communicate the framework, the objectives, and the ways in which different instruments will be used to achieve the goals of monetary policy. Any changes in the framework should be pre-announced and their rationale explained as well (Poirson, 2008).

46. Finally, the timing of policy moves is important. More frequent reviews would help enhance the predictability of policy-making, by ensuring that policy is set mainly in the context of well-anticipated policy reviews, except in exceptional circumstances (Poirson, 2008). In countries which exhibit significant co-movement of their MCI with that of the United States, moving to a pre-announced schedule for policy decisions may also help focus market participants on domestic monetary conditions, rather than on developments abroad. 
47. Empirically, there is a weak positive correlation (at least in our sample) between numerical transparency measures and financial openness. Based on the NergizEichengreen measure, transparency appears to have been a main ingredient of successful strategies adopted by some of the most financially integrated countries (United Kingdom, Euro Area). That said, while these countries (United Kingdom, Euro Area) exhibit high levels of transparency, based on these ratings, many of the emerging countries with inflation targeting regimes have achieved comparable levels of transparency (Figure 12). ${ }^{19}$

\footnotetext{
${ }^{19}$ Related to this, we find using a different measure of transparency (based on observance of certain principles, as defined in the IMF's Standards and Codes Gateway), that the overall monetary policy transparency of the least financially open countries in our sample is broadly similar (even slightly higher) than that of the most financially open countries (on average).
} 


\section{Box 1. India: Key Capital Account Restrictions (As of end-September 2007)}

Foreign Institutional Investment in equity is restricted to approved foreign institutional investors (FIIs), up to 30 percent of capital. Investment in government and corporate debt is capped at US\$2.6 billion and US $\$ 1.5$ billion; FIIs are also restricted from buying unlisted corporate debt. There are no restrictions upon associated outflows, viz. repatriation of profits. Short-term gains (below a year) are taxed at 10 percent; longer-term gains are tax-exempt.

Foreign Direct Investment is limited at 74 percent in private banks, telecoms, satellites and atomic minerals, 51 percent in single-brand retailing, 49 percent in air transport services and investing companies in infrastructure /services, 26 percent in defense, insurance, oil refining and publishing news and current affairs and 20 percent in radio. It is prohibited in retail trading, atomic energy, lottery, gambling, real estate business, and agricultural businesses such as tea plantations. Composite caps, i.e., covering portfolio and direct investment, apply in the case of banks, telecoms and radio, while investment in insurance can only be through joint ventures. Official approval is required when the foreign investor has an existing venture in the same field.

External Commercial Borrowings (ECBs) face a minimum average maturity of 3 years (up to US $\$ 20$ million) and 5 years (US\$20-500 million); additional loans of up to US\$250 million can be raised if they have an average maturity of 10 years. Funding cost must be below Libor plus 200 basis points (3-5 years' maturity) and Libor plus 350 basis points for maturities greater than 5 years. Conversion of ECBs into equity is allowed if certain conditions are met. Capital raised abroad through global or American depository receipts is prohibited for domestic financing of investment in real estate and the stock market at home. Prepayment of ECBs is subject to a \$500 million annual limit.

Short-term external borrowing is subject to a US\$20 million ceiling applied to import-linked shortterm loans, per transaction and for permissible imports. Trade-related foreign loans with 1-3 year maturity and up to US\$20 million are allowed for capital goods imports. Funding costs cannot exceed Libor plus 50 basis points for credits up to 1 year, and Libor plus 125 basis points for credits with $1-3$ year maturity.

Domestic banks' investments abroad are subject to open position limits and must have a residual maturity of less than a year and at least an AA(-1) rating. They can invest non-residents non-repatriable foreign currency deposits abroad in long-term fixed income instruments (minimum AA- rating) with maturity below that underlying these deposits. Opening of offshore banking units is subject to Foreign Exchange Management Act regulations. Indian companies' investments in join ventures and wholly owned subsidiaries abroad are capped at 400 percent of their net worth.

Portfolio investments abroad are limited to $\$ 5$ billion for all mutual funds. Individual funds can invest up to 10 percent of net assets, up to $\$ 200$ million each. Residents and corporates are limited to $\$ 200,000$ a year and 50 percent of their net worth, respectively. 


\section{Box 2. Turkey}

In recent years, Turkey has successfully adapted its monetary framework to the challenges posed by financial globalization. Starting earlier this decade, burgeoning capital inflows have proved challenging to macroeconomic management. ${ }^{1}$ Between 2002 and 2006, the capital account balance rose from roughly zero to $\$ 45$ billion (11 percent of GDP); over the same time period, the lira substantially appreciated in real effective terms.

Increased confidence in the Turkish economy contributed to rising capital inflows and upward shifts in money demand, which complicated conduct of the monetary targeting regime that had been maintained since the abandonment of the crawling peg in February 2001. In 2006, the Central Bank of Turkey (CBT) moved from the monetary targeting regime to inflation targeting. The emphasis on price stability is explicitly enshrined in the CBT Law, which states that "the primary objective of the Bank shall be to achieve and maintain price stability" (Article 4). ${ }^{2}$

The target is medium-term in nature, with end-year targets for the CPI set jointly with the government for the coming three years. It is currently centered on a 4 percent point target with a plus and minus 2 percent tolerance band; supply-side shocks and changes in international liquidity conditions are explicitly mentioned, along with other factors, as a rationale for building in some flexibility around the target. When inflation falls outside of the tolerance band, the CBT issues an open letter to the government explaining the reasons for the breach and the measures to be taken to bring inflation back to its point target.

In addition to the formalities of inflation targeting, the CBT has also emphasized clear communication in the new framework. The CBT produces a quarterly Inflation Report with forecasts for the output gap and inflation, as well as uncertainty bands for the latter, and an analysis of risks to price stability. In addition, it issues press releases following the preannounced monthly meetings of the Monetary Policy Committee (MPC), at which decisions about policy rates (interbank and repo/reverse repo rates) are made. Summary reports discussing the Committee's views on the inflation outlook are also issued within eight working days of the MPC's meetings.

Monetary operations also adapted to allow for more flexible liquidity management. To ensure that the money market interest rates remain close to its benchmark borrowing rate, the CBT absorbs liquidity through its overnight deposit (at the posted benchmark rate) and repos on the Istanbul Stock Exchange (ISE). In the past, when confronted with the need to mop up "excess liquidity" from the market at times of lira weakness, the CBT has temporarily resorted to one- and two-week deposit auctions validating interest rate well above the posted benchmark (overnight) rate. In the opposite case of liquidity shortages that may push the overnight money market rate well above the benchmark rate, the CBT stands ready to supply liquidity to the market through one-week repo auctions to be conducted in the ISE at 1 percentage point above the benchmark rate target." ${ }^{3}$ To improve its ability to deal with long-lasting bulges in excess liquidity, the CBT has also recently issued central banks notes with maturities of up to 91 days. 


\section{Box 2. Turkey, Concluded}

At the same time, exchange-rate policy has become nondiscretionary. After the abandonment of the crawling peg regime and the adoption of a pure floating regime, the CBT announced in July 2001 that it would only intervene to limit excessive volatility in the exchange market. ${ }^{4}$ Moreover, since April 2002, the CBT has conducted transparent and pre-announced purchase auctions, with the aim to build foreign exchange reserves for prudential reasons (reserves do not yet fully cover short-term debt on a remaining maturity basis). The CBT's motive to build reserves is well understood in the markets, and the small size of interventions is deliberately calibrated to avoid disturbing market prices. Foreign exchange purchases are typically sterilized, to avoid compromising the monetary stance. Indeed, high domestic interest rates have been maintained to bring inflation down to the 4 percent target, and this in turn has put upward pressure on the exchange rate.

${ }^{1}$ See Ali Culha, “A Structural VAR Analysis of the Determinants of Capital Flows into Turkey”, Research Department Working Paper No 06/05, Central Bank of the Republic of Turkey, October 2006, for discussion of the drivers of capital inflows and their macroeconomic effects.

${ }^{2}$ The law also states that "The Bank shall, provided that it shall not be in conflict with the objective of achieving and maintaining price stability, support the growth and employment policies of the Government.”

${ }^{3}$ See Annual Report of the Central Bank of the Republic of Turkey, 2006, page 37.

${ }^{4}$ See Ozge Akici, Olcay Yucel Culha, Umit Ozlale, and Gulbin Sahinbeyoglu, "Causes and Effectiveness of the Foreign Exchange Interventions for the Turkish Economy,” Research Department Working Paper No 05/05, Central Bank of the Republic of Turkey, February 2005. The study found that interventions tended to dampen volatility (but did not have an effect on the trend of the exchange rate). The same result is found in Guamaraes and Caracadag, "The Empirics of Foreign Exchange Intervention in Emerging Markets: The Cases of Mexico and Turkey,” IMF WP 04/123, 2004. 


\section{Box 3. Malaysia}

Malaysia's experience illustrates the complexity of monetary management in a globalizing economy. The central bank of Malaysia has two main monetary policy objectives—sustainable growth and low inflation. Despite exiting from the peg against the U.S. dollar in July 2005, the central bank also intervenes in the foreign exchange market and has stated that exchange rate stability remains an important goal. In addition, the central bank pursues financial stability. Since the early 1990s, Malaysia has experienced bouts of capital inflows and outflows that have complicated monetary policy. Malaysia's monetary policy framework uses interest rates as the main operating target of monetary policy. Since April 2004, the Bank Negara Malaysia (BNM)has been signaling its policy stance through the Overnight Policy Rate (OPR). Market based liquidity operations are aimed at ensuring the appropriate level of liquidity that would influence the overnight interbank interest rate to move closer to OPR. In addition, Malaysia has used capital controls on inflows (1994) and outflows (1997 crisis), providing room for monetary maneuvering in spite of a fixed exchange rate regime.

Prior to the mid-1990s, the monetary policy strategy had been based on targeting monetary aggregates. During this period, the BNM influenced the day-to-day volume of liquidity in the money market, consistent with monetary targeting. Private net capital inflows of long-term capital rose from 5.7 percent of GDP in 1990 to 8.2 percent of GDP in 1993, while net short-term inflows increased from 1.2 percent of GDP to 8.9 percent during the same period. ${ }^{1}$ Strong macro fundamentals and favorable interest rate differentials contributed to these large inflows. To neutralize the effects of intervention in the foreign exchange market, the central bank sterilized the domestic liquidity, first by selling government securities from its stock, and later by issuing its own paper. Apart from being costly, the sterilization operations increased domestic interest rates and continued to attract capital flows. In addition, the authorities also increased reserve requirements of banks to mop up liquidity. The fiscal stance during this period was tight. However, the real exchange rate appreciated significantly owing to higher inflation. Faced with a trade-off between keeping interest rates high to contain inflationary pressures and the need to discourage short-term inflows, the authorities imposed temporary controls on short-term inflows. This strategy seemed to have in succeeded in containing short-term inflows and most of the controls were removed in 1994.

The large capital inflows in 1992-93 and their reversal in 1994 exposed the limitations of monetary targeting (that may have partly to do with instability of money demand), and resulted in a shift to interest rate targeting in the mid-1990s. However, the ability of the central bank to influence domestic interest rates, based on domestic considerations, was again tested during the Asian crisis. At that time, amidst capital outflows and excessive exchange rate volatility, the trade-off was between raising interest rates to attract capital inflows and containing the downturn. The controls imposed by the authorities during this episode were wider ranging, combining temporary controls on outflows with exchange controls. 


\section{Box 3. Malaysia, Concluded}

Afterwards, the management of monetary policy focused primarily on maintaining the exchange rate peg. Liquidity management aimed at keeping interest rate at levels conducive to economic growth, exploiting the room for maneuver created by the capital controls. ${ }^{2}$ Between 1998 and 2003, BNM was able to effect monetary policy based on domestic policy objectives, mainly because most of the inflows were on account of trade flows, rather than capital flows. Apart from strong fundamentals, mainly reflected in growth and inflation, many prudential and administrative controls still in place, helped in balancing capital flows and financial stability.

In the first half of 2005, capital inflows surged with the expectation of a currency revaluation, resulting in a large accumulation of reserves. From September 1998 to July 2005, the ringgit was pegged to the U.S. dollar. In July 2005, Malaysia shifted to a managed float against an undisclosed trade-weighted basket of currencies. Following the change in exchange rate regime, the ringgit was under significant downward pressure as some speculative positions were unwound. The central bank resorted to intervention to prevent ringgit depreciation. In 2006, Malaysia experienced renewed net inflows and exchange rate pressure, which the central bank countered through sterilized intervention. Subsequently, during the equity sell off in July 2006, the central bank again intervened to prevent ringgit depreciation. Since end-2005, intervention has been mainly one-sided.

The experience of Malaysia demonstrates that the commitment to exchange rate stability has posed challenges to the maintenance of low inflation in episodes of capital inflows. ${ }^{3}$ Malaysia's experience managing volatile capital flows during the 1990s offers interesting lessons. First, it demonstrates the limitations of sterilization over long periods. In the face of continuous inflows, a country can only temporarily resist appreciation pressures. The experience underscores the need for a large "war chest" of securities on the one hand, and the

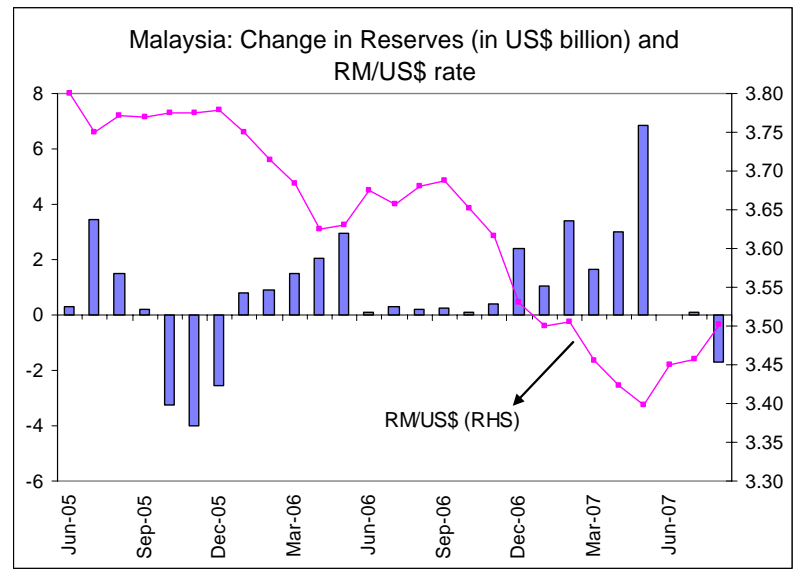
problem of high interest rates inducing larger capital inflows, on the other. It also shows that controls on capital inflows can be effective, although only for short periods of time (in fact, controls were unwound over time starting in 1999, particularly after 2003).

${ }^{1}$ Ariyoshi, Akira and others, 2000, IMF, Capital Controls, Country Experiences with their Use and Liberalization, IMF Occasional Paper No. 190.

${ }^{2}$ Cheong, Latifah 2005. “Globalization and the operation of monetary policy in Malaysia, in BIS papers No 23, Globalization and monetary policy in emerging markets, 2005.

${ }^{3}$ Robert McCauley, Understanding monetary policy in Malaysia and Thailand: Objectives, instruments and independence, BIS, March 2006. 


\begin{tabular}{|c|c|}
\hline & Table 1. Monetary Instruments in the Most Financially Globalized Co \\
\hline HK SAR & $\begin{array}{l}\text { Sales and purchases of Hong Kong dollars for U.S. dollars when the HK\$/US\$ exchange rate reaches } \\
\text { the weak (strong) side convertibility undertaking, respectively, under the Linked Exchange Rate } \\
\text { System to prevent the HK\$ from moving outside the trading band. The weak (strong) side } \\
\text { convertibility undertaking is } 7.85 \text { (7.75) HK\$/US\$. } \\
\text { Discount Window: Banks can borrow Hong Kong dollar funds overnight through repurchase } \\
\text { agreements using Exchange Fund paper as collateral. The discount rate on the first half of the bank's } \\
\text { holdings of the Exchange Fund paper is the maximum of } 150 \text { bps over the U.S. Federal Funds rate } \\
\text { target and the average five-day moving average of the overnight and one-month HIBOR rates. The rate } \\
\text { on the remaining Exchange Fund paper is the maximum of } 500 \text { bps above this rate, and the daily } \\
\text { overnight HIBOR rate. }\end{array}$ \\
\hline Singapore & $\begin{array}{l}\text { Open market operations: daily using short-term money market instruments with fixed tenors: SGS } \\
\text { repos/reverse repos; FX swaps/reverse swaps; and direct borrowing/lending. } \\
\text { Standing facilities: end of day liquidity facility ( } 2 \text { percent over 1-month SIBOR); intra-day liquidity } \\
\text { facility; borrowing and lending rates (+ - } 50 \text { basis points of reference rate, equal to the weighted } \\
\text { average of dealer bids for overnight deposits). } \\
\text { Other: } 3 \text { percent Minimum Cash Balance, unremunerated, with 2-week averaging provisions between } \\
2 \text { percent and } 4 \text { percent. Foreign exchange interventions (aimed at maintaining the currency within an } \\
\text { unannounced trade-weighted band). }\end{array}$ \\
\hline $\begin{array}{l}\text { Belgium } \\
\text { (ECB) }\end{array}$ & $\begin{array}{l}\text { Open market operations: Refinancing operations (one week and three months); ad-hoc fine tuning } \\
\text { operations; structural operations. The weekly 7-day OMO is conducted at a rate marginally above the } \\
\text { policy rate (minimum repo bid rate). The 3-month OMO repo is conducted at market rate. } \\
\text { Standing operations: overnight marginal lending and deposit facilities with rates set at +, - } 100 \text { basis } \\
\text { points policy rate. } \\
\text { Other: } 2 \text { percent reserve requirement, remunerated at the policy rate; full reserve averaging; } \\
\text { maintenance period set to coincide with Governing Council meetings which decide on the policy rate. }\end{array}$ \\
\hline UK & $\begin{array}{l}\text { Open market operations: Weekly repos (circa } 1 \text { week maturity, depending on timing of policy } \\
\text { meeting) conducted at the Bank/policy rate; overnight fine tuning operations at end of monthly } \\
\text { maintenance period; monthly long-term repos (3, 6, 9, and } 12 \text { month maturities) conducted at market } \\
\text { rate (will in time be replaced largely by the outright purchase of longer-term securities). } \\
\text { Standing facilities: overnight lending and deposit facilities with rates set at +, - } 100 \text { basis points Bank } \\
\text { rate ( } 25 \text { basis points on the final day of the maintenance period). } \\
\text { Other: no reserve requirement; contractual reserves remunerated at the Bank rate; full averaging; } \\
\text { maintenance period starting on MPC announcement date and ending the day before the next MPC } \\
\text { meeting. }\end{array}$ \\
\hline India & $\begin{array}{l}\text { Open market operations: Market stabilization bonds (91-day to } 1 \text { year); liquidity adjustment facility } \\
\text { (overnight). } \\
\text { Liquidity adjustment facility: repo and reverse repo operations (overnight). } \\
\text { Other: } 7.5 \text { percent Cash Reserve Ratio, to be fully met on a weekly basis; at least } 70 \text { percent of the } \\
\text { requirement also has be met on a daily basis; foreign exchange intervention (aimed at smoothing } \\
\text { volatility) }\end{array}$ \\
\hline \multicolumn{2}{|c|}{ 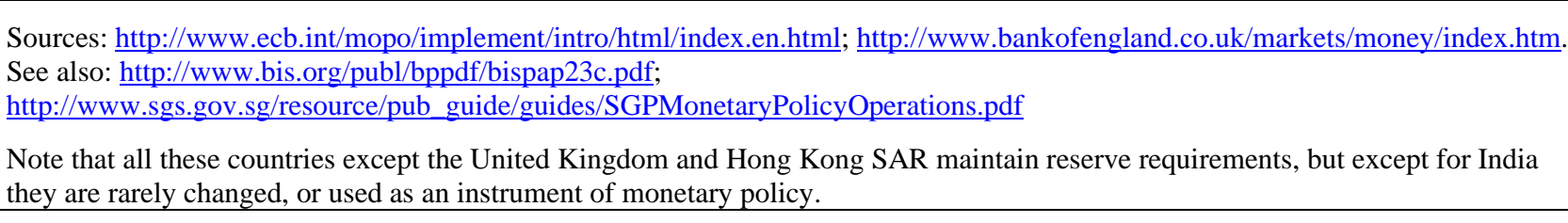 } \\
\hline
\end{tabular}


Figure 1. Measures of Financial Openness

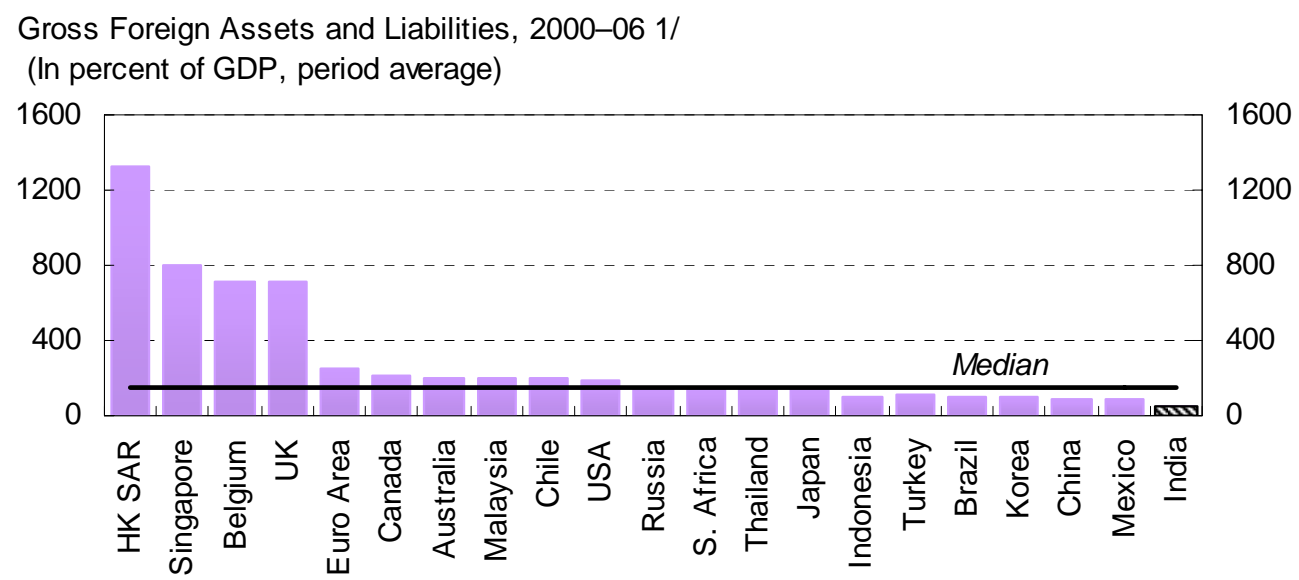

Gross Capital Flow 2/

(In percent of GDP, period average)

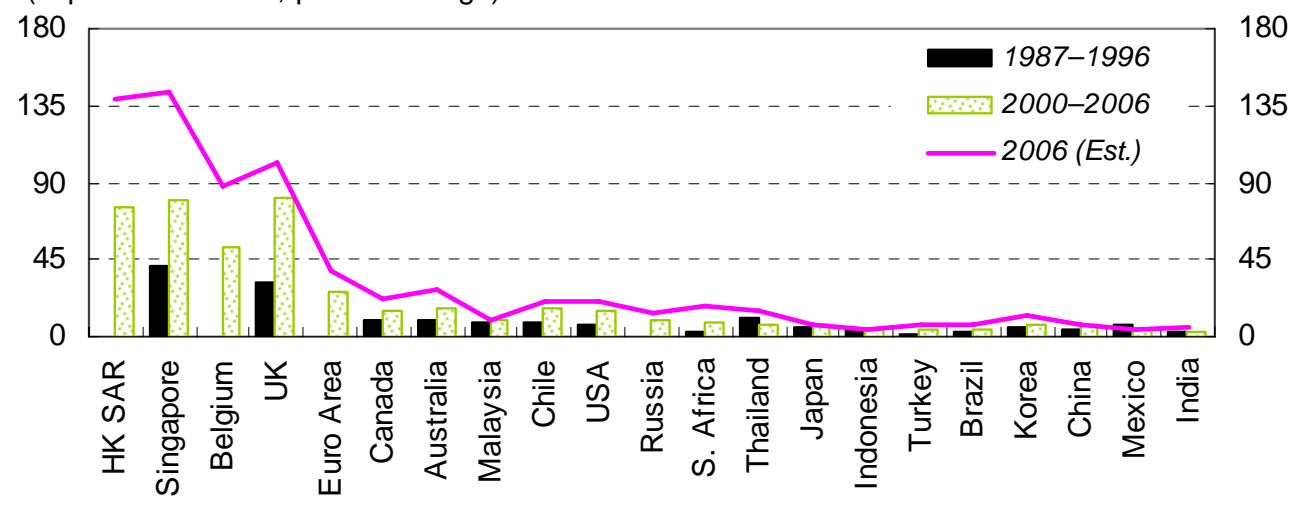

Capital Inflow 2/

(In percent of GDP, period average)

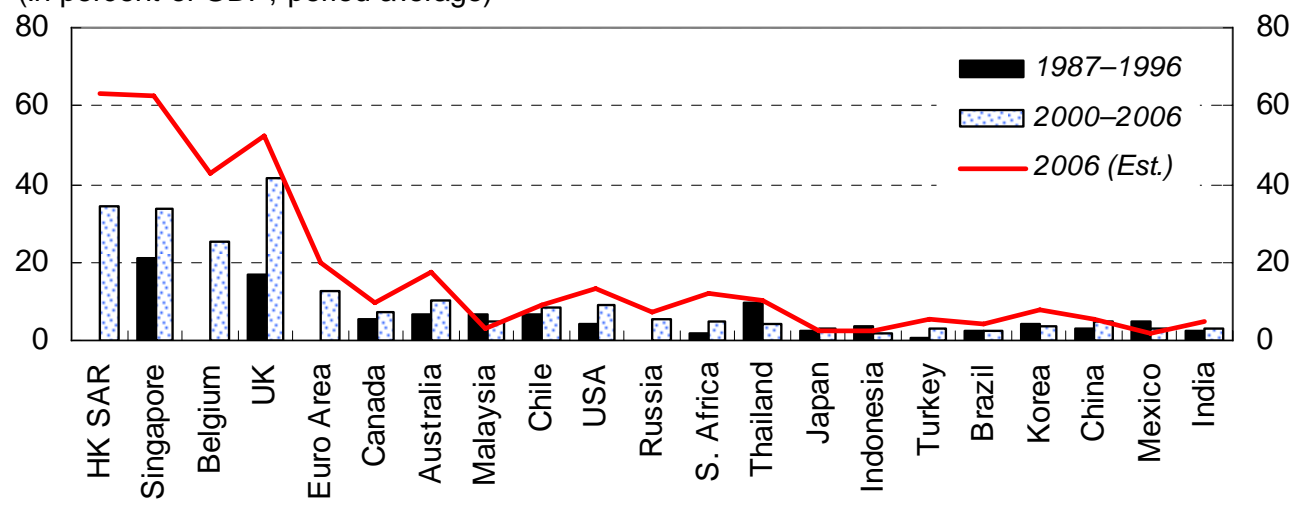

Sources: Lane, Philip R. and Gian Maria Milesi-Ferretti (2005); and IMF, International Financial Statistics, World Economic Outlook and staff calculations.

1/ Malaysia, Chile, Russia, South Africa, Turkey, Brazil and India are plotted for the period 2000-05 and Belgium for 2002-05.

2/ HK SAR, Belgium, Euro Area and Russia are not plotted for the period of 1987-96 due to lack of sufficient data. Belgium is plotted for the period of 2002-06. 
Figure 2. Measures of Capital Account Openness, 2000-05

The Abiad-Detragiache-Tressel Index 1/

(Period average)

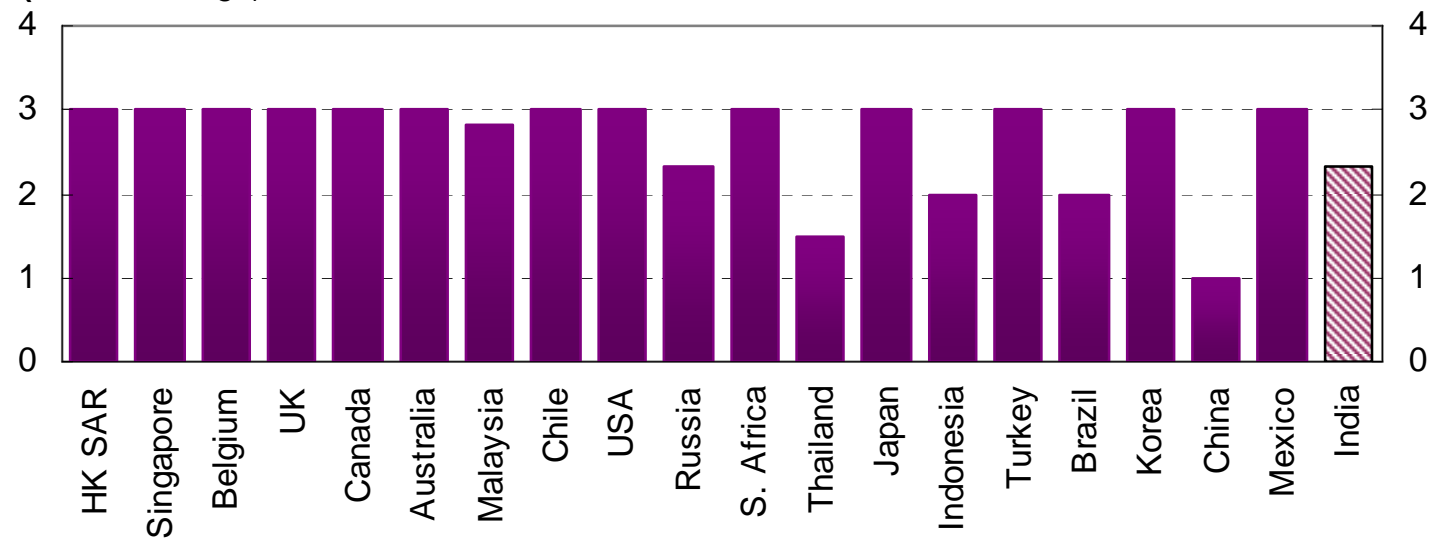

The Chinn-Ito Index 2/

(Period average)

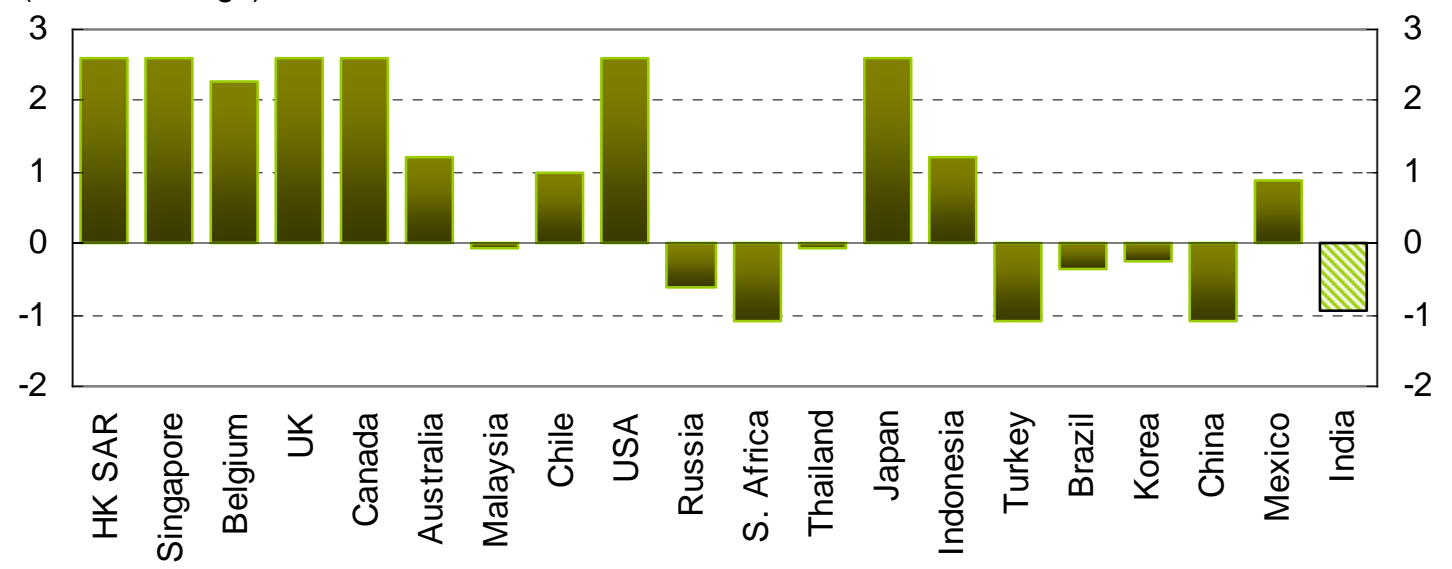

Sources: Prof. Menzie David Chinn, University of Wisconsin; Abiad, Abdul, Enrica Detragiache and Thierry Tressel (2007), preliminary draft; and IMF staff calculations.

1/ It can take values on a scale from zero to three, with higher score representing liberalization and lower score indicating highest degree of financial repression.

2/ A higher value indicates that a country is more open to cross-border capital transactions. 
Figure 3. Financial Openness and Policy Regime, 2000-06

Gross Capital Flow

(In percent of GDP; countries arranged by monetary policy target, defined as of 2004)

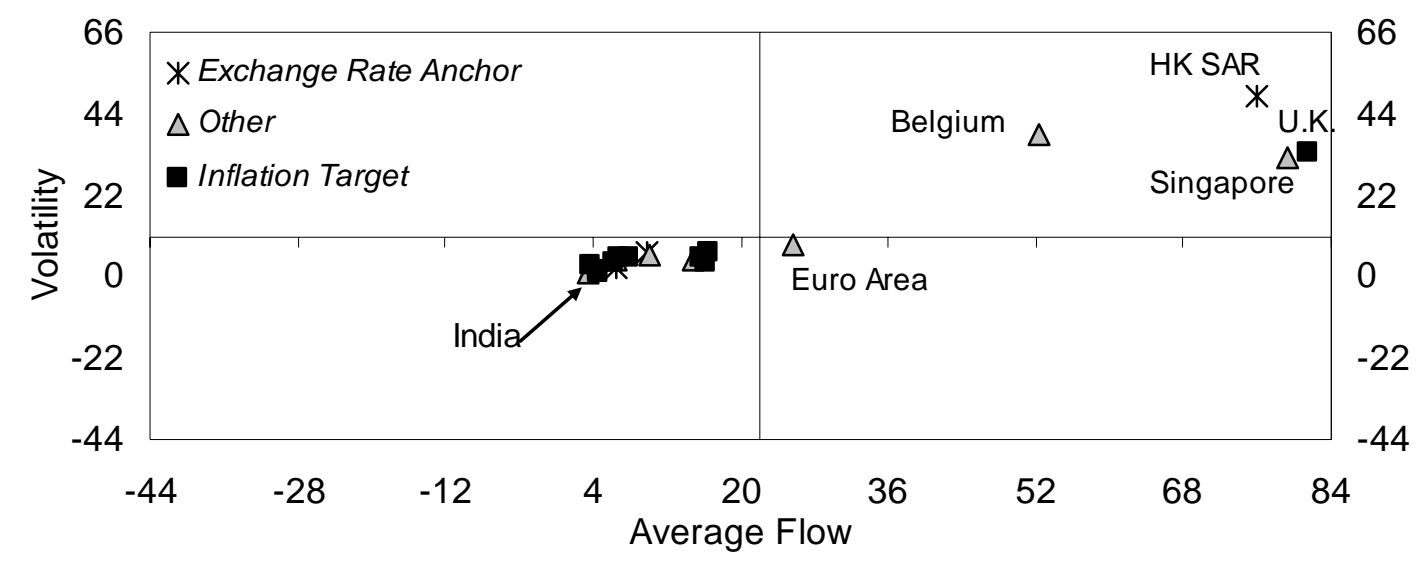

Gross Capital Flow

(In percent of GDP; countries arranged by exchange rate target, defined as of 2004)

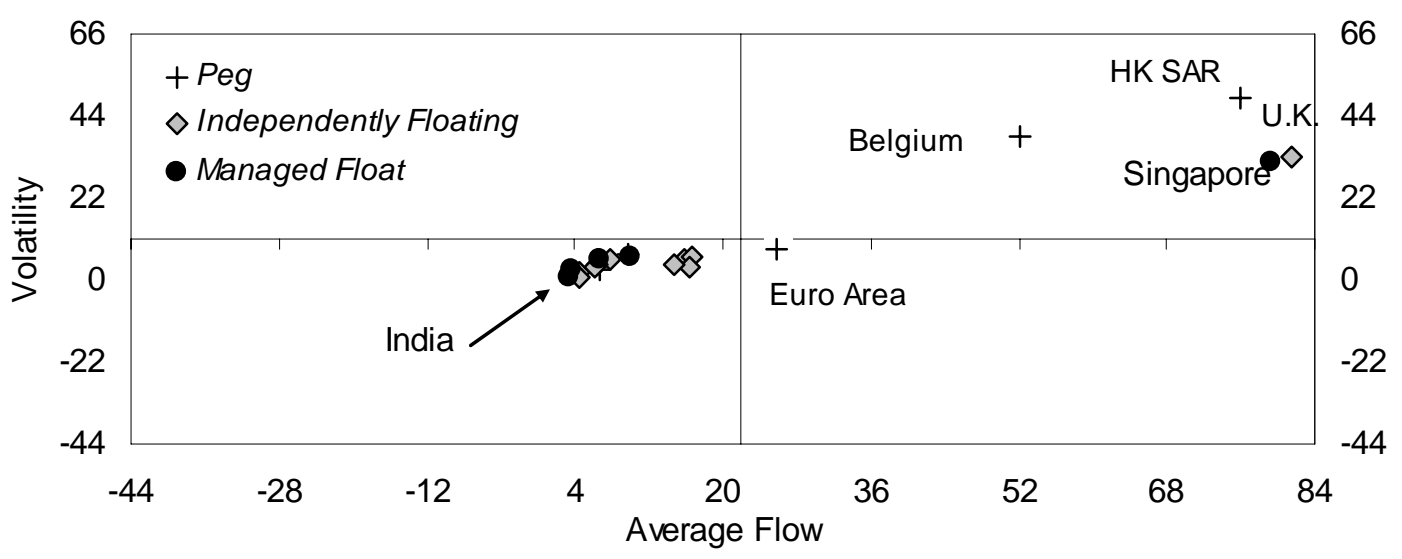

Sources: IMF, International Financial Statistics, World Economic Outlook and staff calculations. 


\section{Figure 4. India: Capital Flows}

Net Foreign Institutional Investment

(In millions of U.S. dollars)

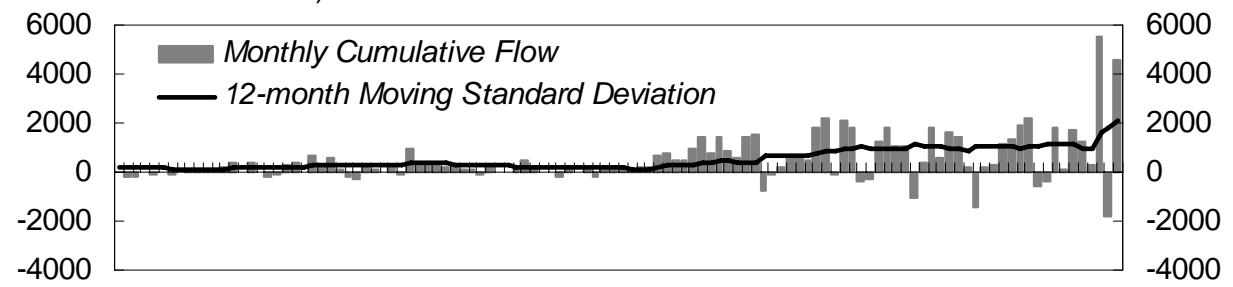

Apr-98 Apr-99 Apr-00 Apr-01 Apr-02 Apr-03 Apr-04 Apr-05 Apr-06 Apr-07

Foreign Direct Investment Inflow

(In millions of U.S. dollars)

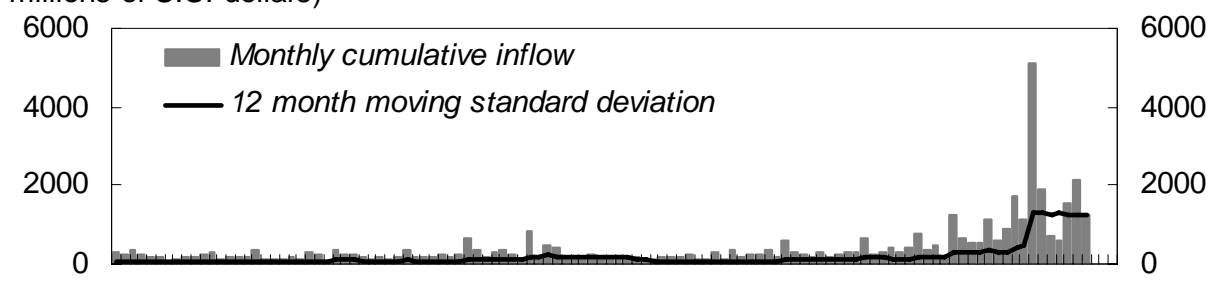

Apr-98 Apr-99 Apr-00 Apr-01 Apr-02 Apr-03 Apr-04 Apr-05 Apr-06 Apr-07

External Commercial Borrowings 1/

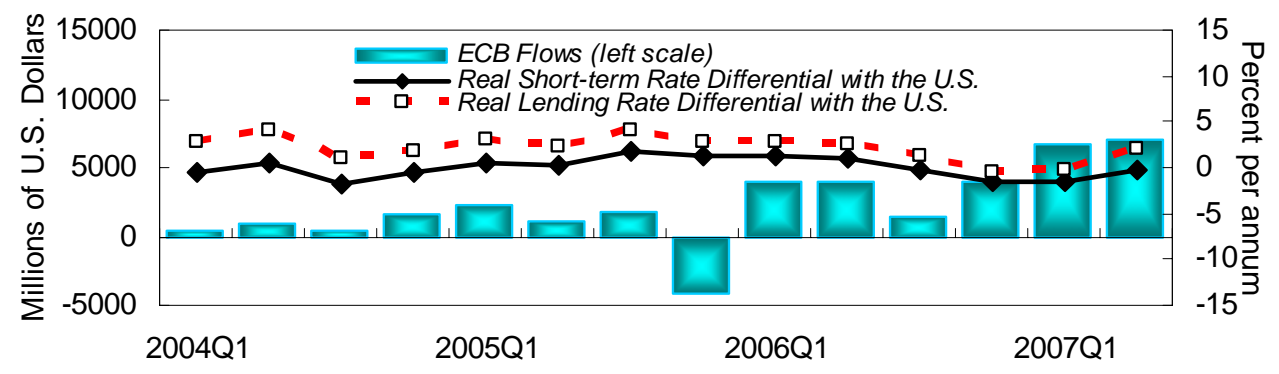

Net Foreign Capital Flow

(In millions of U.S. dollars)

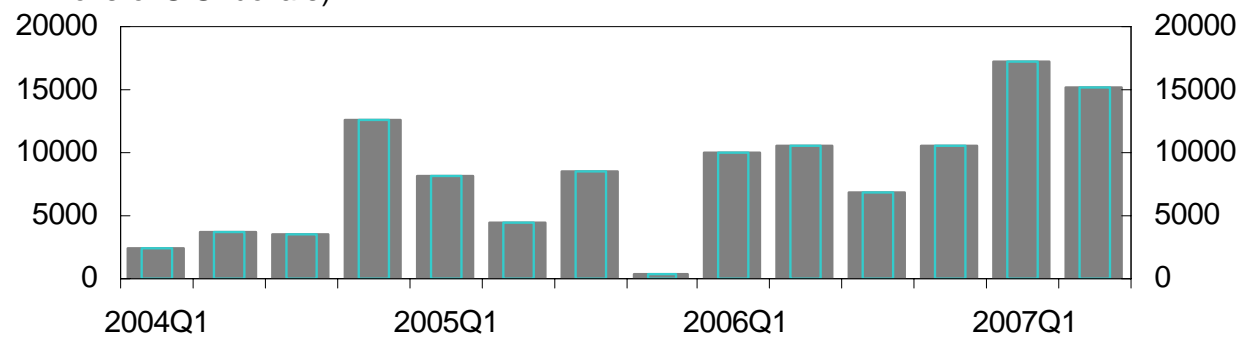

Sources: IMF, International Financial Statistics and staff calculations; CEIC Data Company Ltd.; and Reserve Bank of India.

1/ Three-month secondary market treasury bill yield and prime lending rate are used as the nominal rates in the calculation of real rates. Wholesale price inflation is used for India and consumer price inflation is used for the United States as a proxy for expected inflation rate. 
Figure 5a. India: Foreign Exchange Market

Turnover in Foreign Exchange Market (In billions of U.S. dollars)

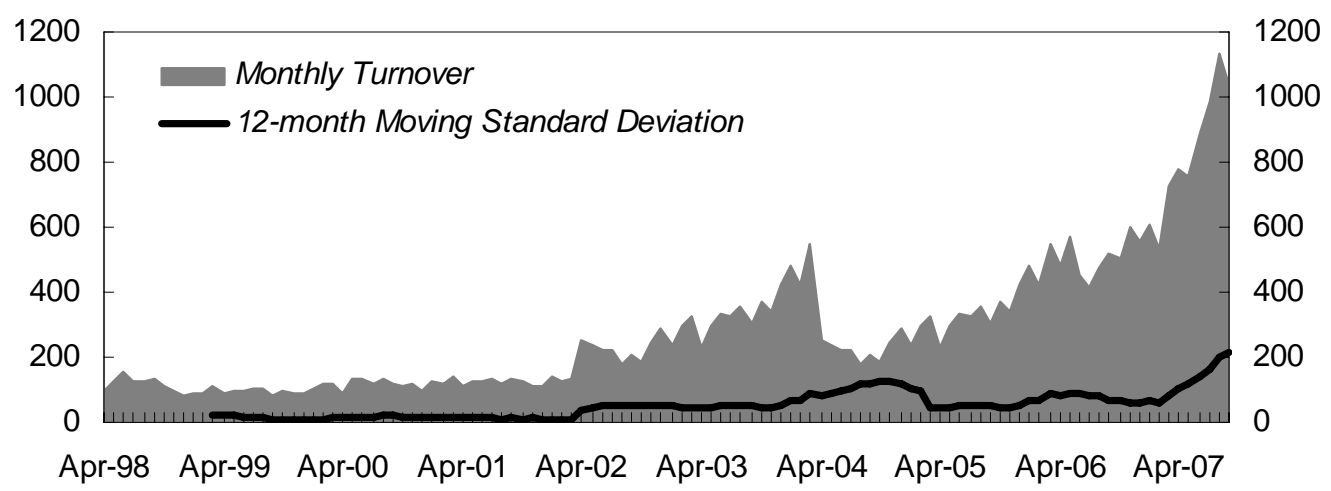

Exchange Rate Volatility

(30-day moving standard deviation of daily log differences)

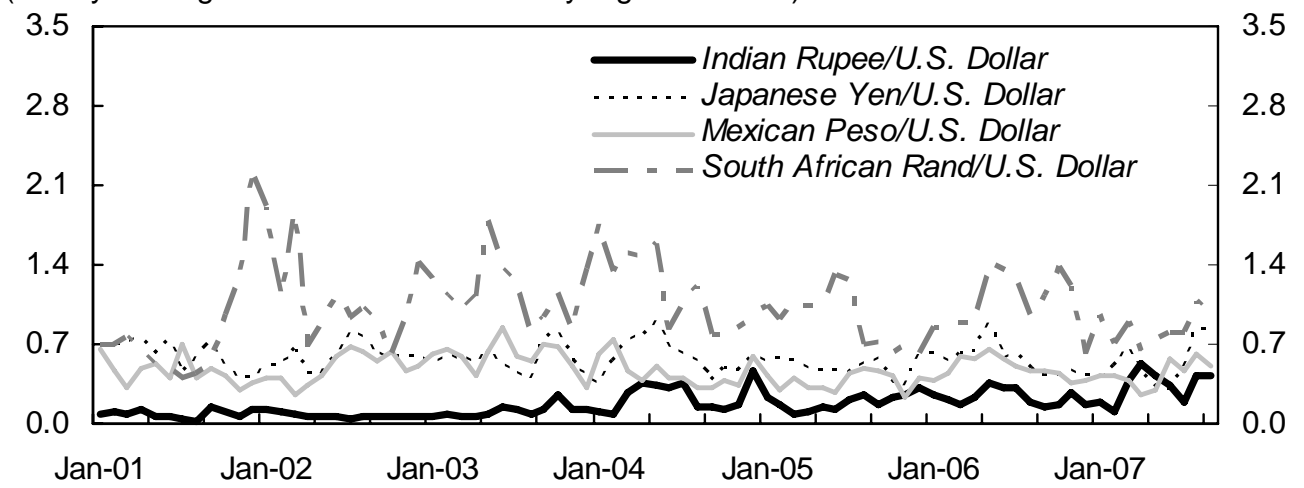

Exchange Market Pressure Index 1/

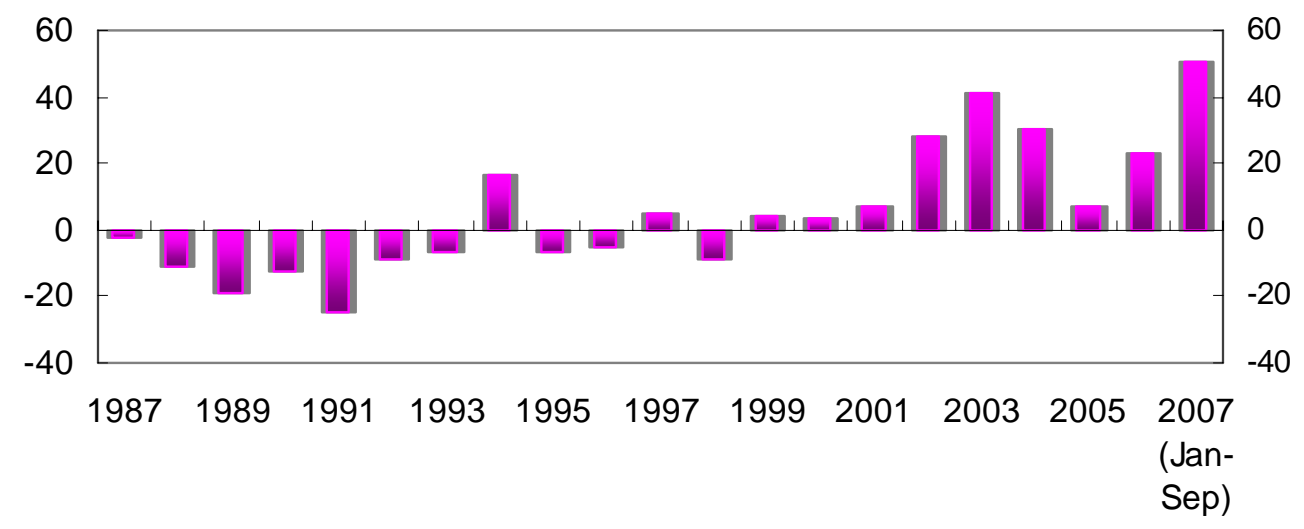

Sources: IMF, International Financial Statistics, World Economic Outlook and staff calculations; CEIC Data Company Ltd.; Bloomberg LP; and Reserve Bank of India.

$1 /$ The index is the sum of rate of appreciation in the nominal exchange rate and accumulation in the foreign exchange reserves normalized by the reserve money stock. 
Figure 5b. India: Monetary Condition

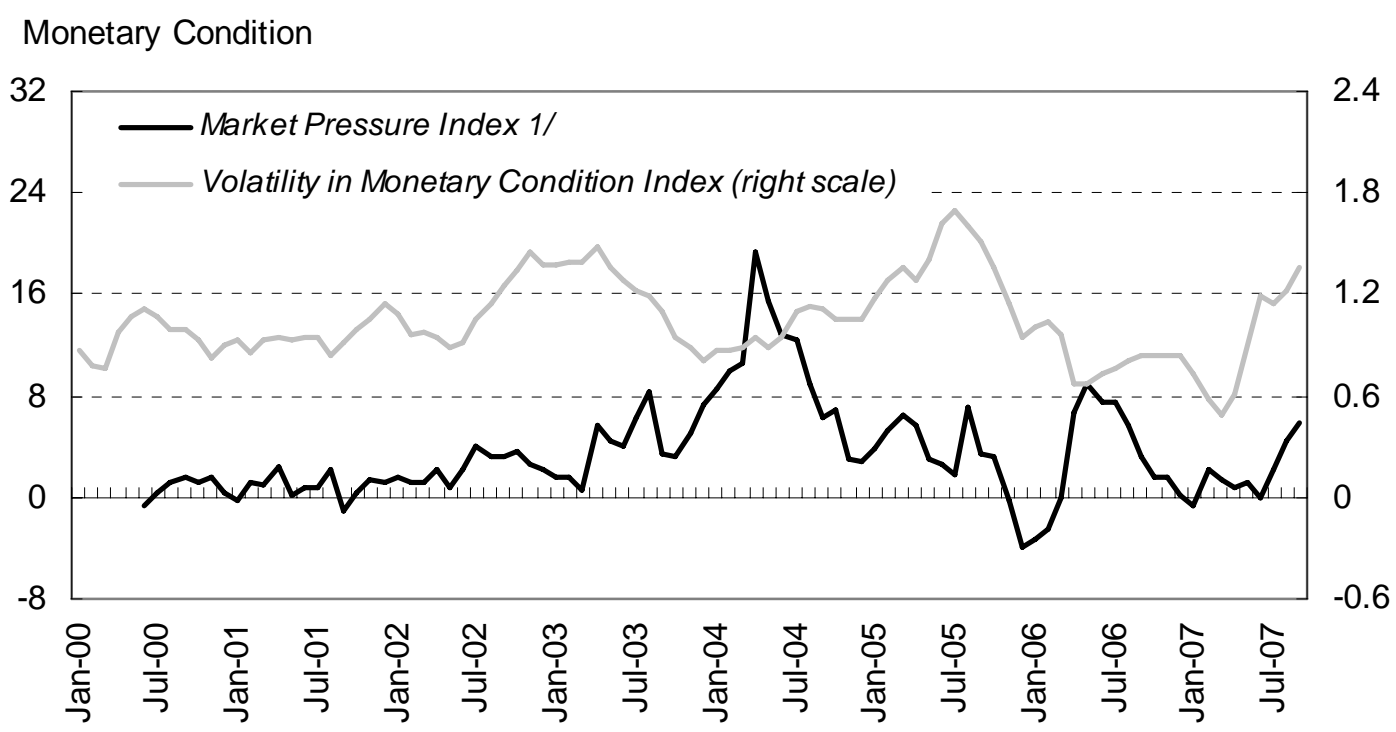

Sources: Reserve Bank of India; and IMF staff calculations.

1/ The index is a weighted sum of domestic liquidity absorption (auctions under the liquidity adjustment facility and market stabilization scheme) and foreign exchange market intervention, normalized by the reserve money. In this computation 80 percent weight was assumed for the domestic liquidity absorption activities. 
Figure 6. Measures of Volatility, 2000-06

Volatility in Reserve Money

(Standard deviation of reserve money to GDP ratio)

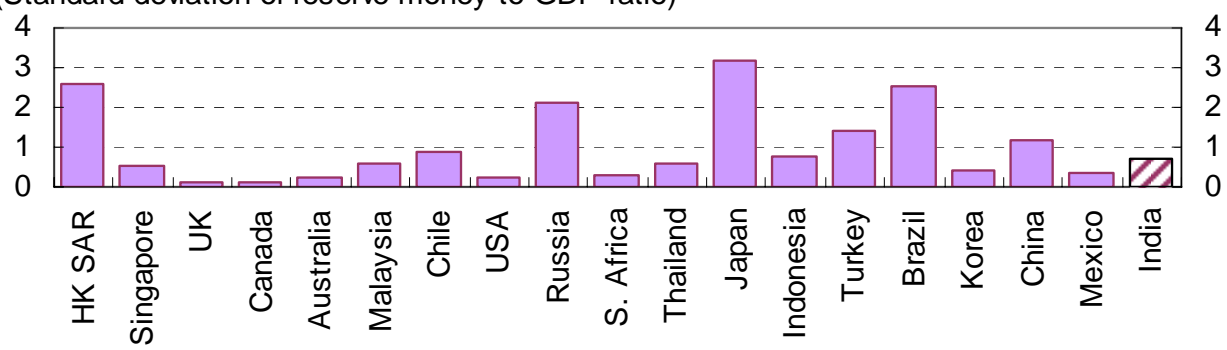

Volatility in Monetary Condition Index

(Standard deviation)

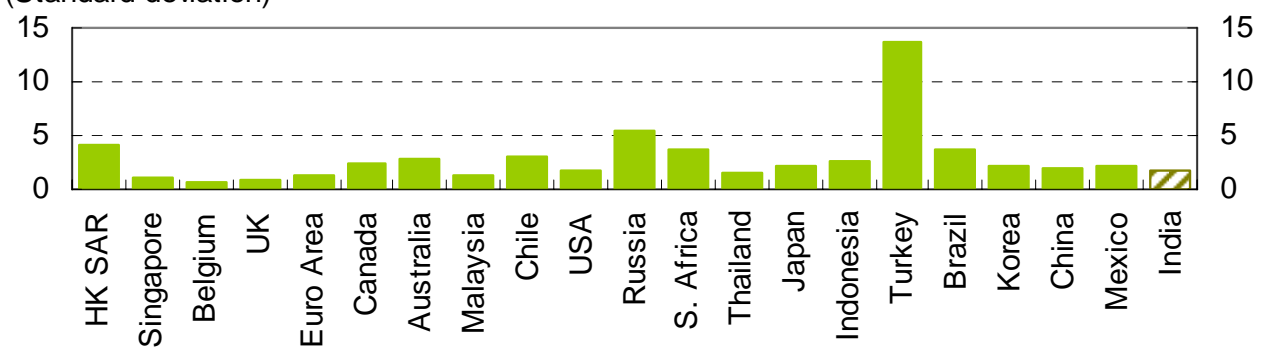

Exchange Rate Volatility 1/

(12-month moving standard deviation of monthly log differences in percent)

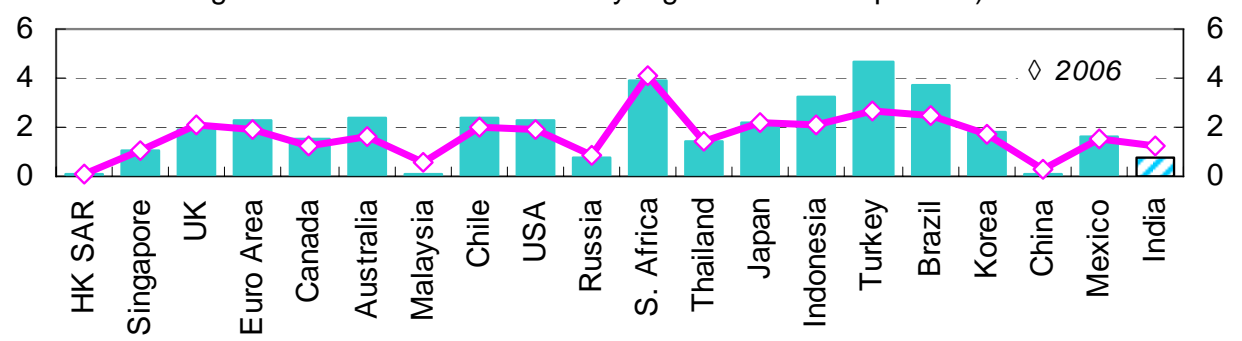

Exchange Market Pressure Index 2/

(Period average)

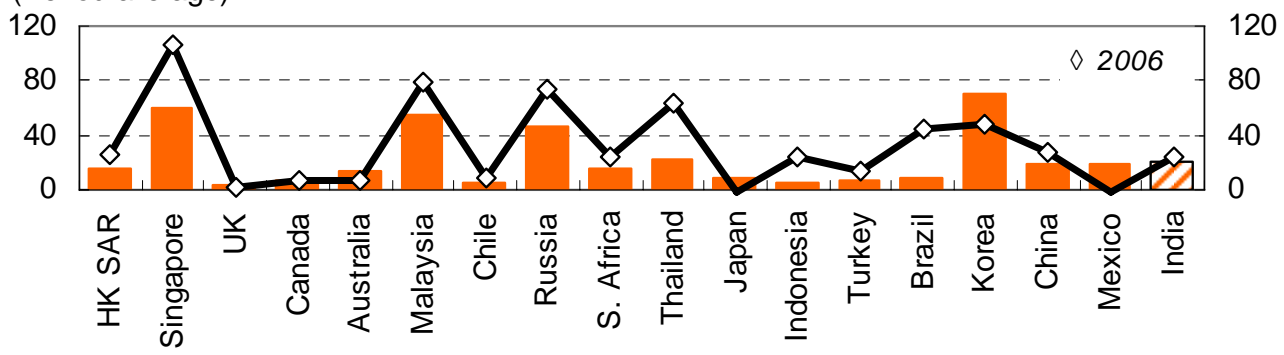

Sources: IMF, International Financial Statistics, World Economic Outlook and staff calculations; CEIC Data Company Ltd.; and Bank of England.

1/ Exchange rates measured as national currency per U.S. dollar except for United States where it is national currency per Euro.

$2 /$ The index is the sum of rate of appreciation in the nominal exchange rate and accumulation in the foreign exchange reserves normalized by the reserve money stock. 
Figure 7a. Financial Openness and Exchange Rate Volatility, 2000-06
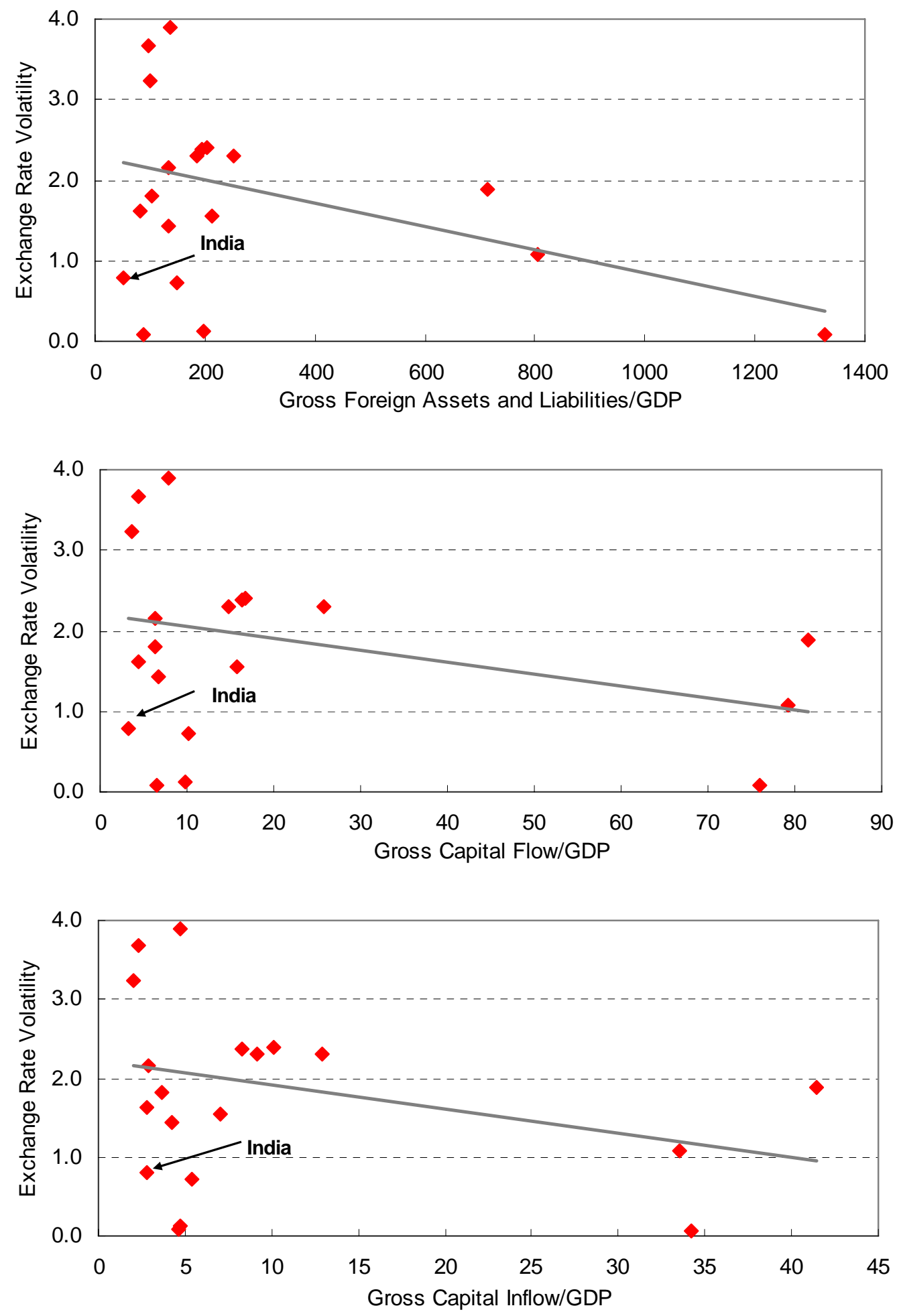

Sources: Lane, Philip R. and Gian Maria Milesi-Ferretti (2005); and IMF, International Financial Statistics, World Economic Outlook and staff calculations. 
Figure 7b. Financial Openness and Exchange Market Pressure Index, 2000-06
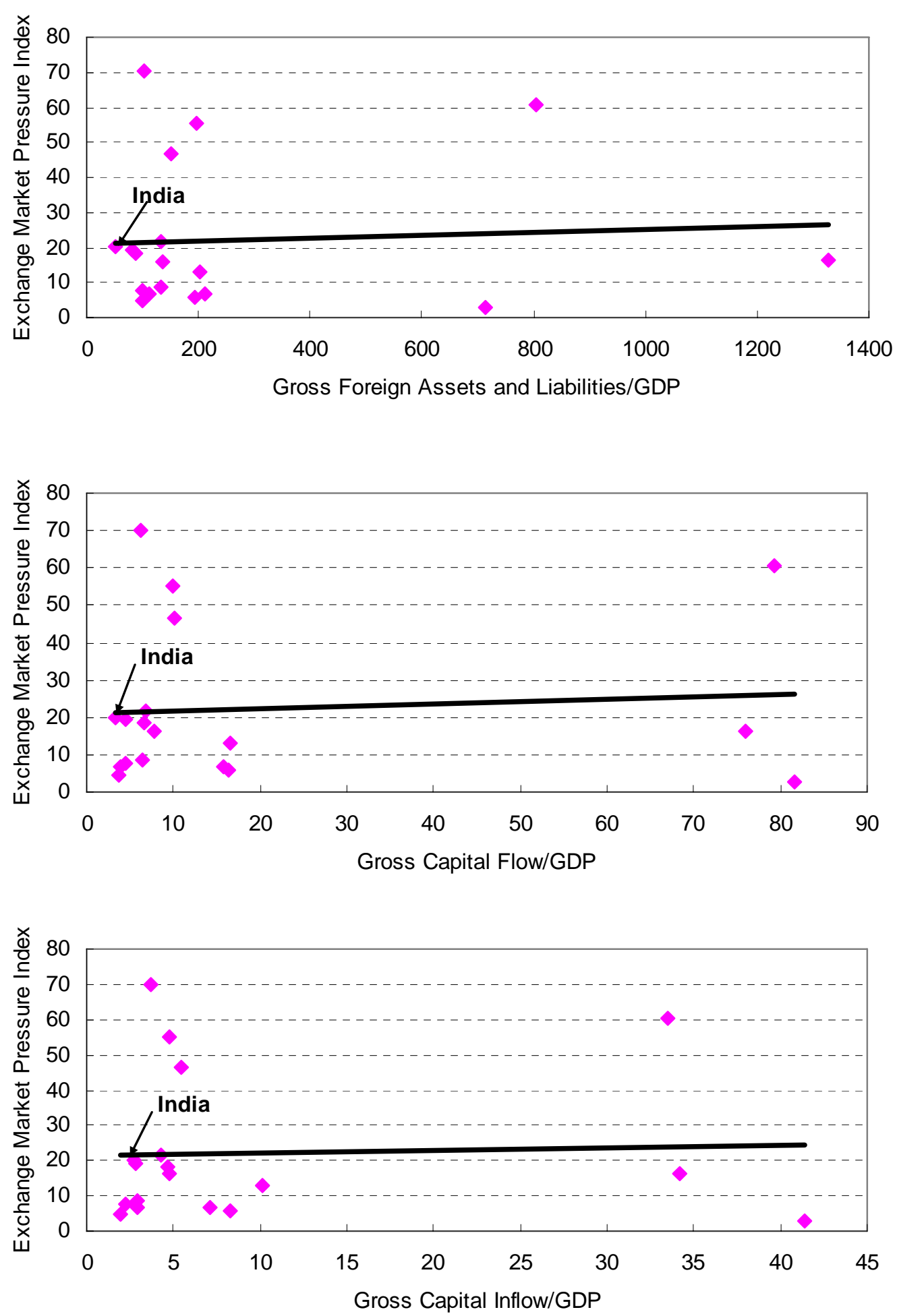

Sources: Lane, Philip R. and Gian Maria Milesi-Ferretti (2005) and IMF, International Financial Statistics, World Economic Outlook and staff calculations. 
Figure 8. Financial Openness and Volatility in Monetary Conditions Index, 2000-06
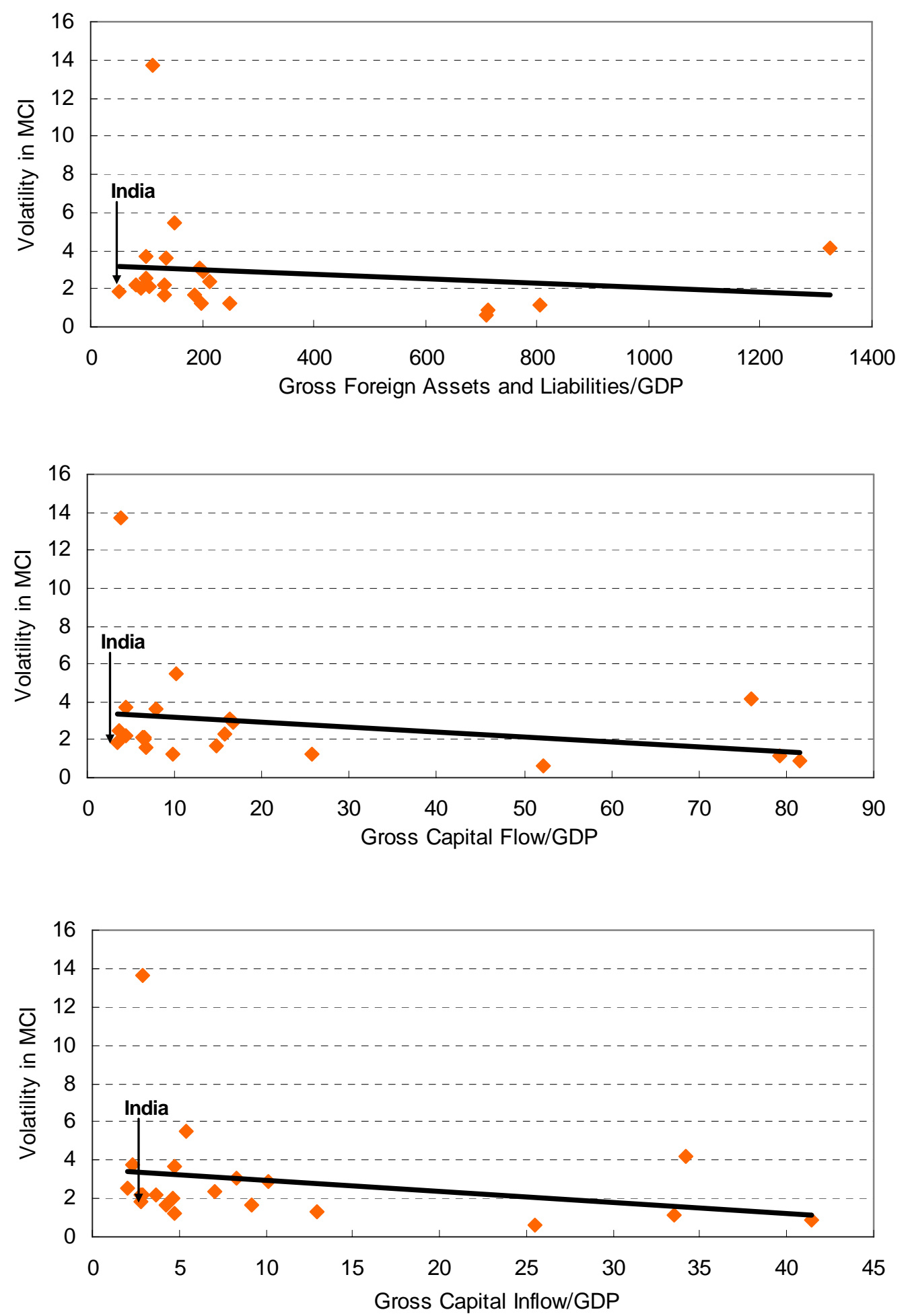

Sources: Lane, Philip R. and Gian Maria Milesi-Ferretti (2005) and IMF, International Financial Statistics, World Economic Outlook and staff calculations. 
Figure 9. Financial Openness and Volatility in Reserve Money, 2000-06
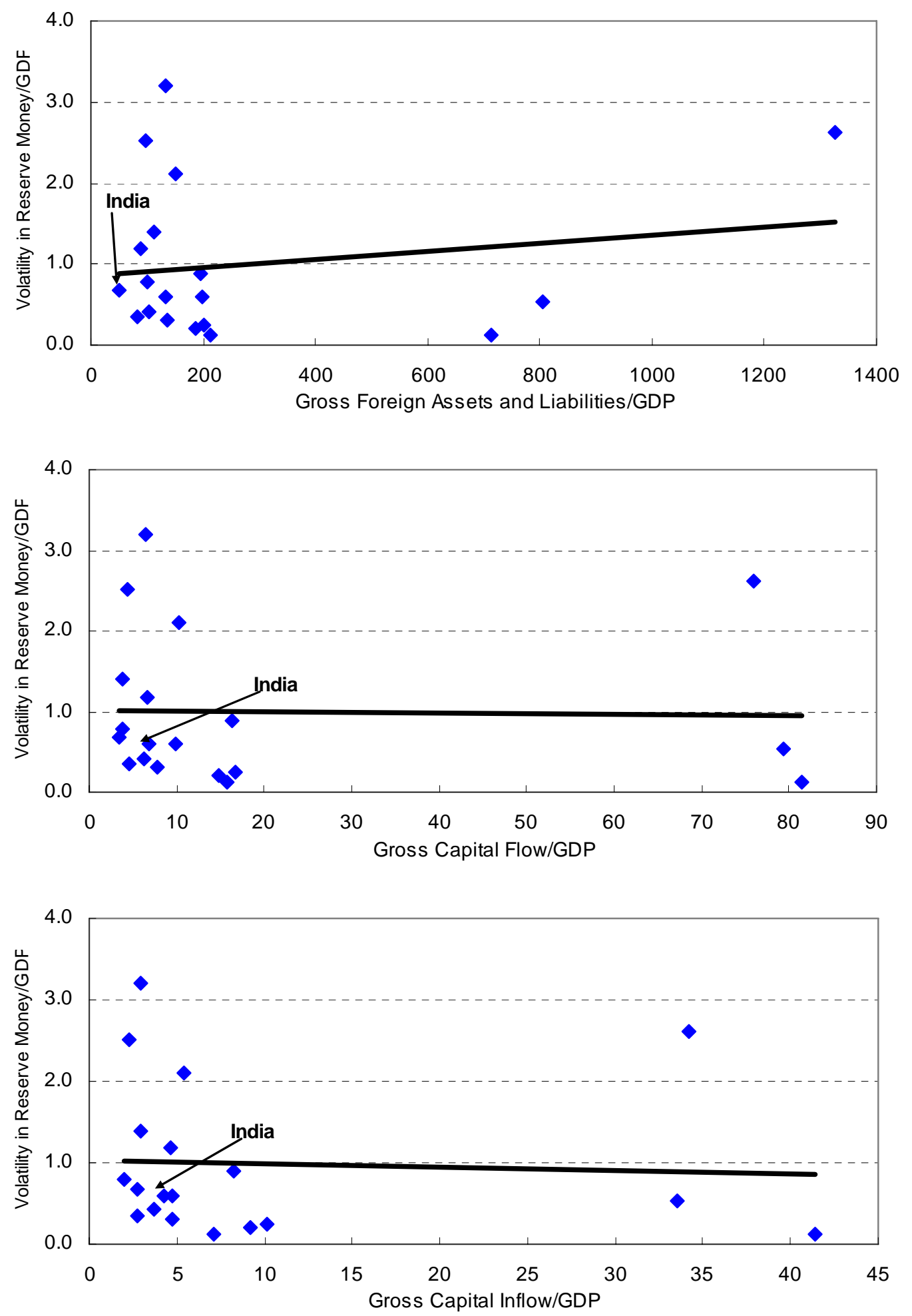

Sources: Lane, Philip R. and Gian Maria Milesi-Ferretti (2005) and IMF, International Financial Statistics, World Economic Outlook and staff calculations. 
Figure 10. Financial Openness and Correlation with U.S. Monetary Conditions Index, 2000-06
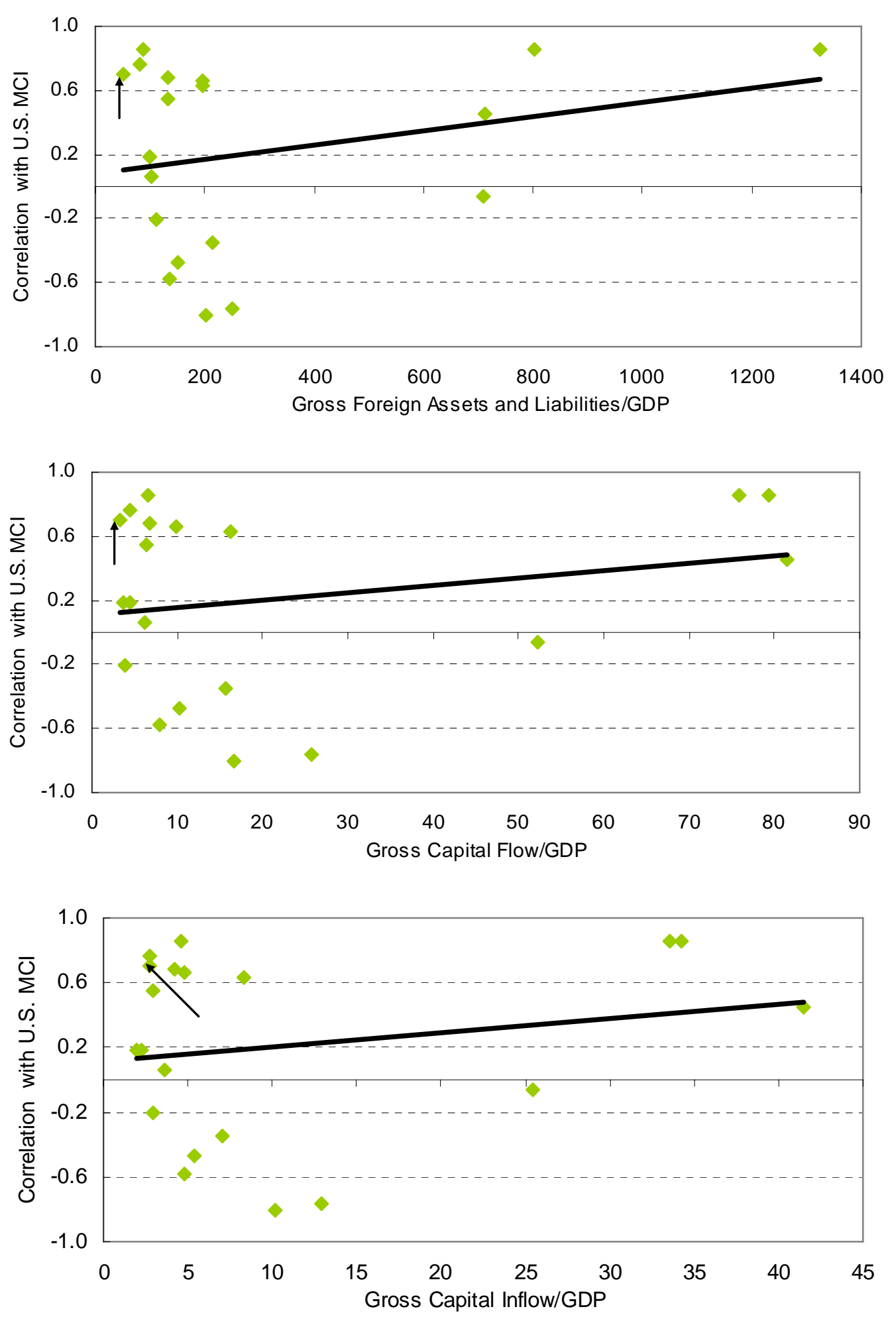

Sources: Lane, Philip R. and Gian Maria Milesi-Ferretti (2005) and IMF, International Financial Statistics, World Economic Outlook and staff calculations. 


\section{Figure 11a. Policy Regime, Financial Openness, and Volatility in Monetary Conditions Index, 2000-06}

Monetary Conditions Index

(Countries arranged by monetary policy target, defined as of 2004)

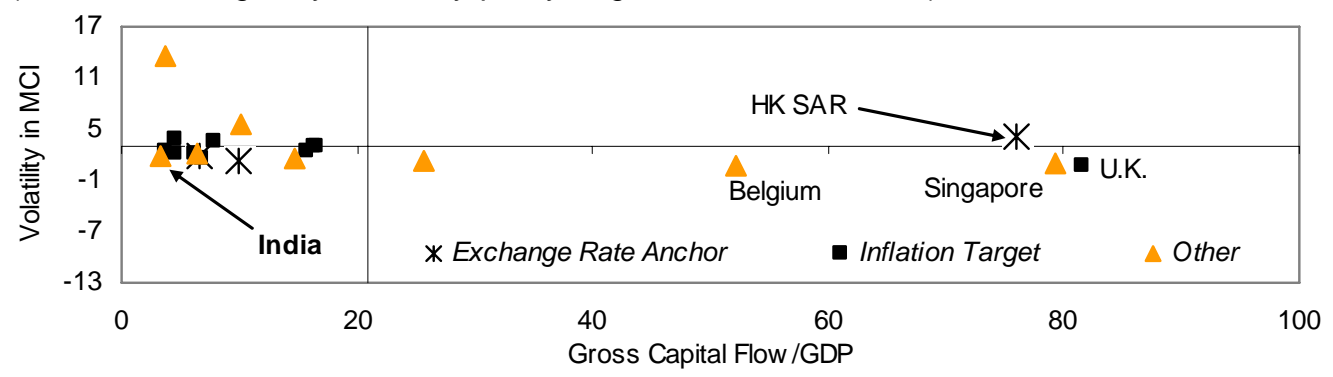

Monetary Conditions Index

(Countries arranged by exchange rate target, defined as of 2004)

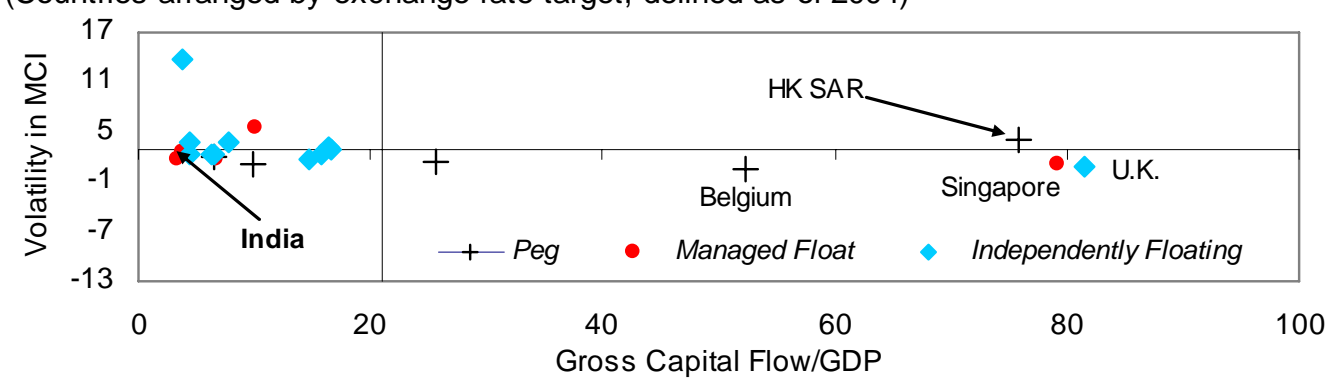

Monetary Conditions Index

(Countries arranged by monetary policy target, defined as of 2004)

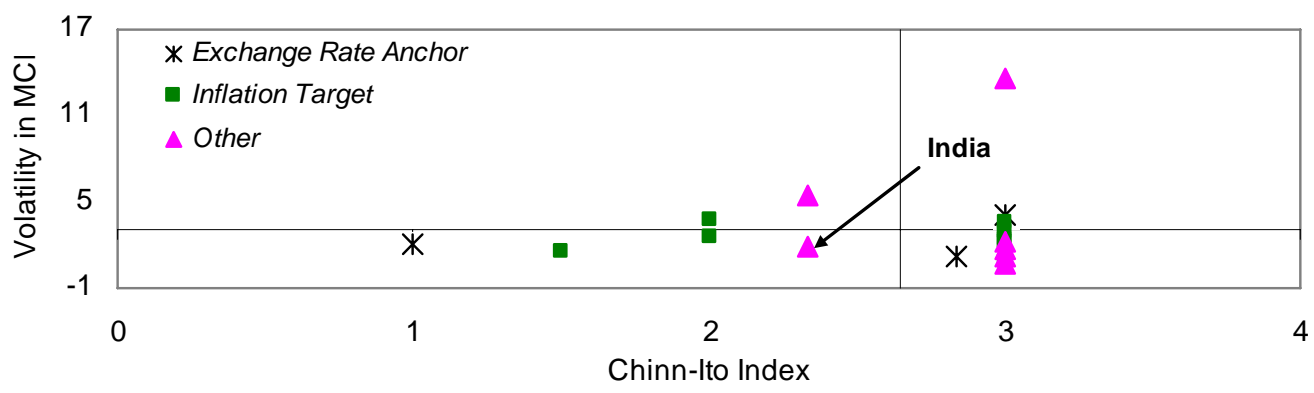

Monetary Conditions Index

(Countries arranged by exchange rate target, defined as of 2004)

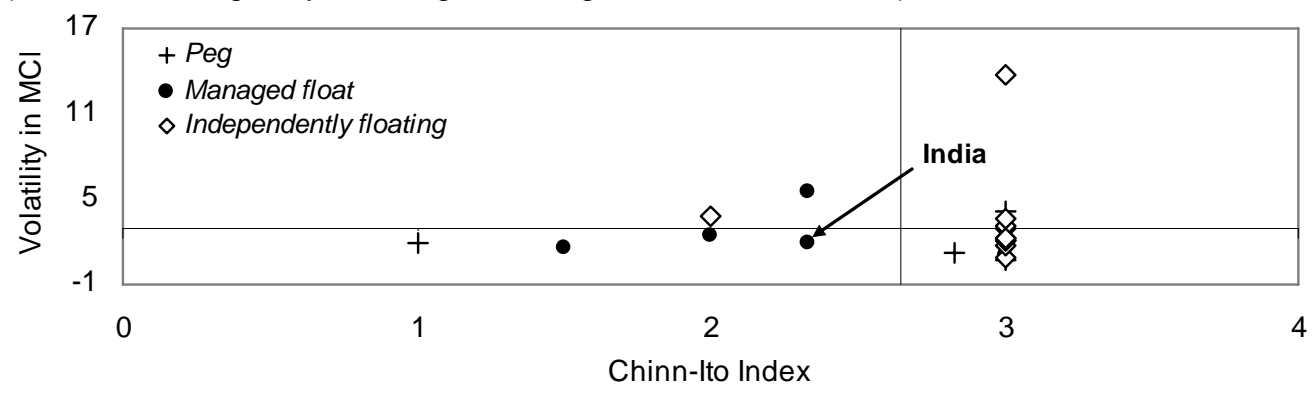

Sources: IMF, International Financial Statistics, World Economic Outlook and staff calculations; and Prof. Menzie David Chinn, University of Wisconsin. 
Figure 11b. Policy Regime and Foreign Exchange Market, 2000-06

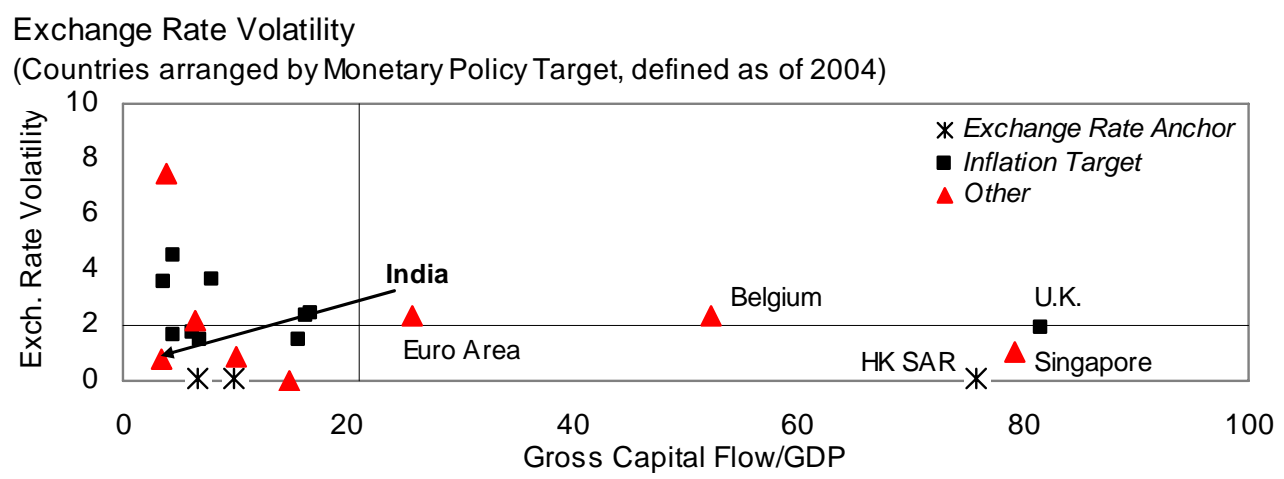

Exchange Rate Volatility

(Countries arranged by Exchange Rate Target, defined as of 2004)

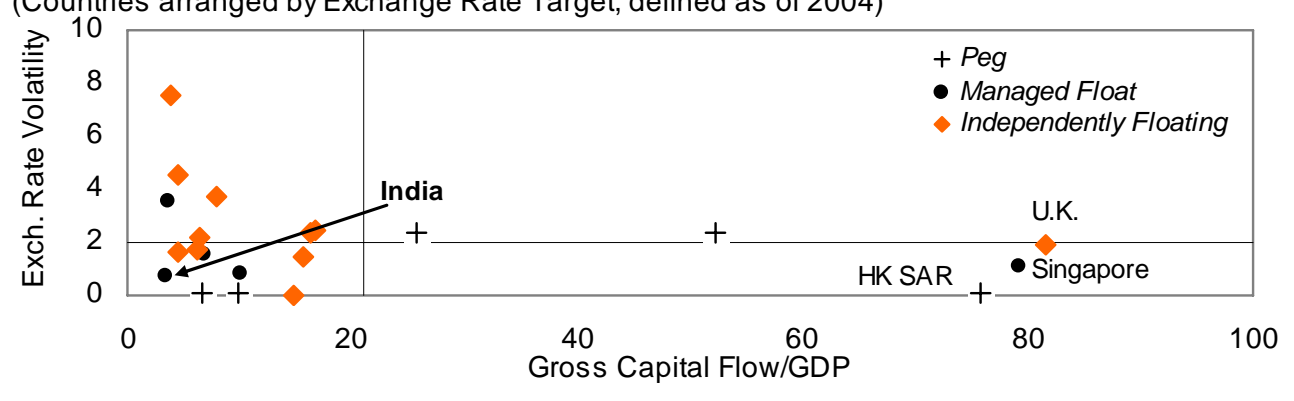

Exchange Market Pressure Index

(Countries arranged by Monetary Policy Target, defined as of 2004)

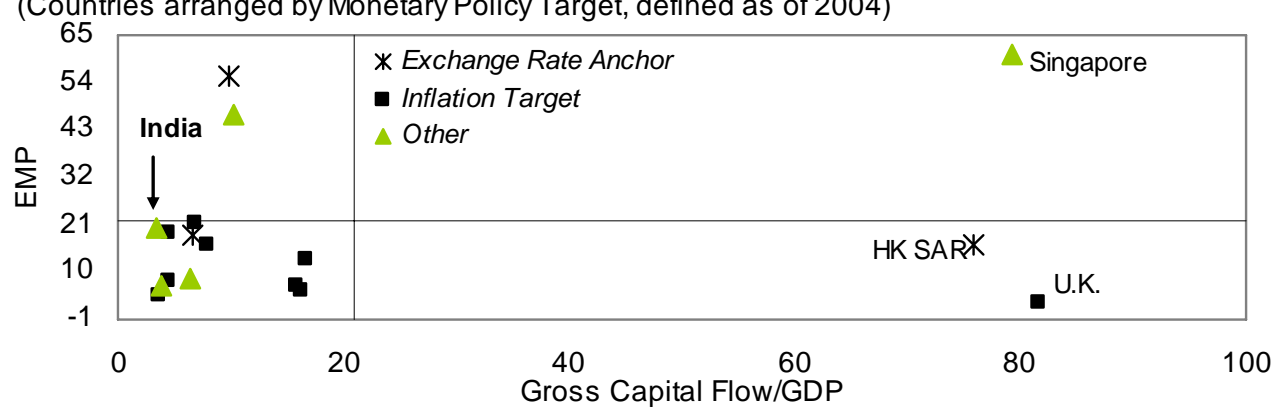

Exchange Market Pressure Index

(Countries arranged by Exchange Rate Target, defined as of 2004)

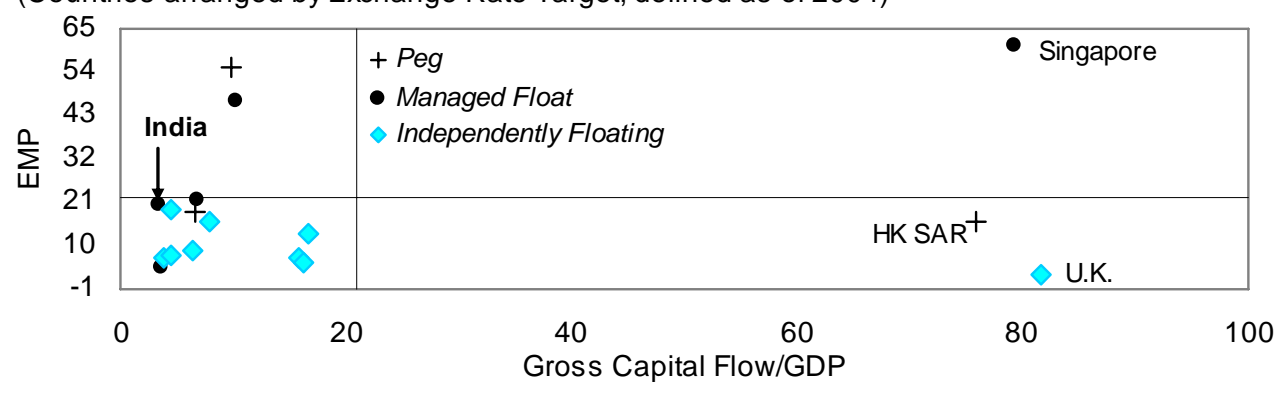

Sources: IMF, International Financial Statistics, World Economic Outlook and staff calculations. 
Figure 12. Capital Flow and Central Bank Transparency, 2000-05 1/

Gross Capital Flow

(In percent of GDP, countries arranged by monetary policy target defined as of 2004)

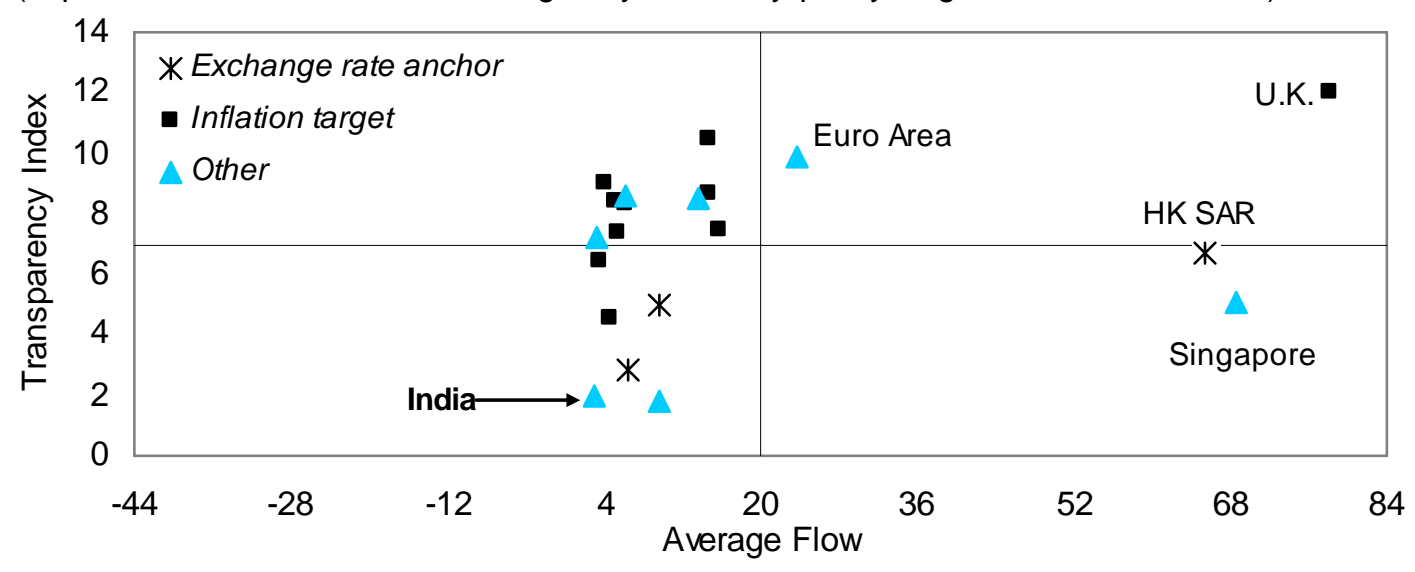

Gross Capital Flow

(In percent of GDP, countries arranged by exchange rate target defined as of 2004)

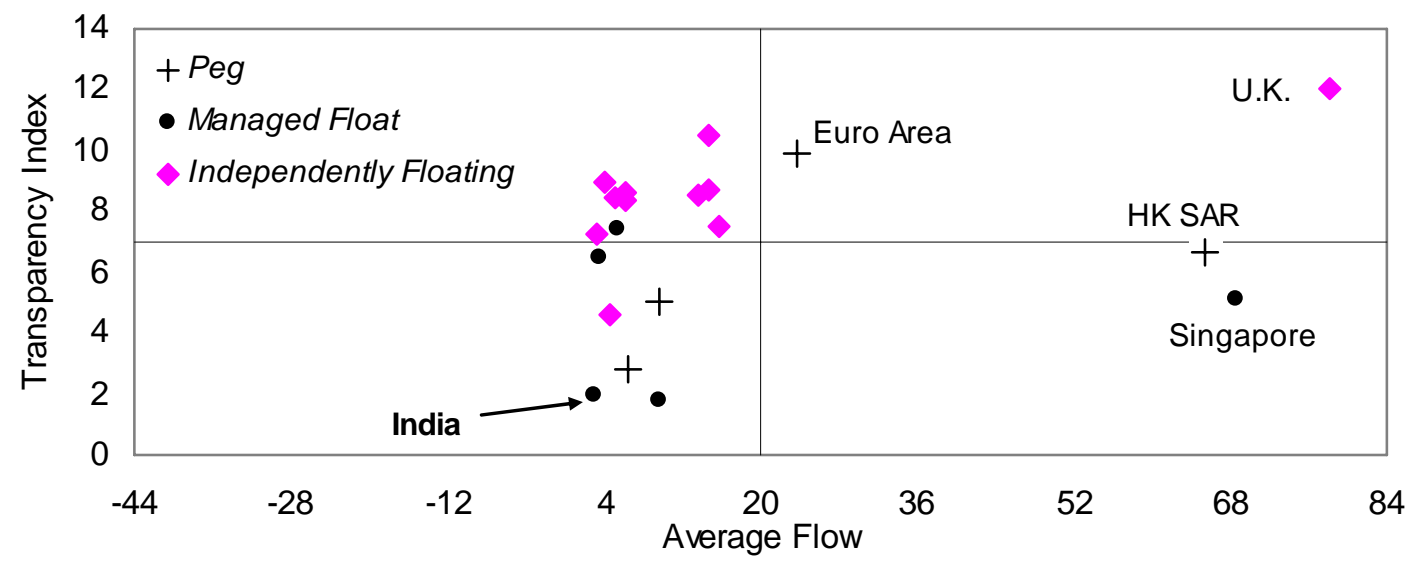

Sources: IMF, International Financial Statistics, World Economic Review and staff calculations; and Dincer, N. Nergiz and Barry Eichengreen (2007): "Central Bank Transparency: Where, Why and with What Effects?", NBER, Working Paper 13003, March 2007.

1/ A higher value indicates more transparent central bank. 


\section{APPENDIX}

\section{Cross-country Summary, 2000-06}

\begin{tabular}{|c|c|c|c|c|c|c|c|c|c|}
\hline \multirow[b]{3}{*}{ Country } & & & \multirow{3}{*}{$\begin{array}{l}\text { Volatility in } \\
\text { Reserve } \\
\text { Money /2 } \\
\text { Standard } \\
\text { Deviation }\end{array}$} & \multirow{3}{*}{$\begin{array}{c}\text { Gross } \\
\text { Foreign } \\
\text { Assets and } \\
\text { Liabilities } 2 / 3 /\end{array}$} & \multirow{3}{*}{$\begin{array}{c}\text { Gross } \\
\text { Capital } \\
\text { Flow 2/ 4/ }\end{array}$} & \multirow[b]{3}{*}{$\begin{array}{c}\text { Capital } \\
\text { Inflow 2/ 5/ }\end{array}$} & \multirow[b]{3}{*}{ EMP Index 5/ } & \multicolumn{2}{|c|}{ Capital Account Openness } \\
\hline & \multicolumn{2}{|c|}{$\mathrm{MCl}($ April 2003=100) 1/ } & & & & & & $\begin{array}{l}\text { Chinn-Ito } \\
\text { Index 6/ }\end{array}$ & $\begin{array}{l}\text { Abiad- } \\
\text { Detragiche- }\end{array}$ \\
\hline & $\begin{array}{l}\text { Standard } \\
\text { Deviation }\end{array}$ & $\begin{array}{c}\text { Correlation } \\
\text { with the U.S. }\end{array}$ & & & & & & & $\begin{array}{l}\text { Tressel } \\
\text { Index } 7 /\end{array}$ \\
\hline Australia & 2.91 & -0.81 & 0.25 & 203.00 & 16.64 & 10.15 & 12.95 & 1.23 & 3.00 \\
\hline Belgium & 0.64 & -0.06 & $\ldots$ & $709^{*}$ & 52.28 & 25.48 & $\ldots$ & 2.28 & 3.00 \\
\hline Brazil & 3.72 & 0.18 & 2.52 & $99^{*}$ & 4.45 & 2.28 & 7.80 & -0.36 & 2.00 \\
\hline Canada & 2.33 & -0.35 & 0.12 & 213.00 & 15.72 & 7.07 & 6.77 & 2.60 & 3.00 \\
\hline Chile & 3.08 & 0.63 & 0.89 & $195^{*}$ & 16.33 & 8.28 & 5.93 & 0.97 & 3.00 \\
\hline China, Mainland & 1.99 & 0.86 & 1.18 & 89.00 & 6.61 & 4.63 & 18.33 & -1.10 & 1.00 \\
\hline Euro Area & 1.27 & -0.77 & $\ldots$ & 251.00 & 25.72 & 12.92 & $\ldots$ & $\ldots$ & $\ldots$ \\
\hline Hong Kong SAR & 4.16 & 0.86 & 2.62 & $1,326.00$ & 75.90 & 34.23 & 16.15 & 2.60 & 3.00 \\
\hline India & 1.84 & 0.70 & 0.68 & 51.00 & 3.36 & 2.77 & 20.10 & -0.93 & 2.33 \\
\hline Indonesia & 2.51 & 0.18 & 0.79 & 100.00 & 3.71 & 1.98 & 4.67 & 1.23 & 2.00 \\
\hline Japan & 2.16 & 0.55 & 3.21 & 133.00 & 6.43 & 2.91 & 8.65 & 2.60 & 3.00 \\
\hline Korea & 2.15 & 0.06 & 0.42 & 104.00 & 6.27 & 3.66 & 70.18 & -0.24 & 3.00 \\
\hline Malaysia & 1.22 & 0.66 & 0.60 & $197^{*}$ & 9.84 & 4.76 & 55.32 & -0.06 & 2.83 \\
\hline Mexico & 2.20 & 0.77 & 0.35 & 82.00 & 4.48 & 2.78 & 19.24 & 0.88 & 3.00 \\
\hline Russia & 5.49 & -0.47 & 2.11 & $150^{*}$ & 10.16 & 5.42 & 46.68 & -0.63 & 2.33 \\
\hline Singapore & 1.14 & 0.86 & 0.53 & 804.00 & 79.29 & 33.53 & 60.51 & 2.60 & 3.00 \\
\hline South Africa & 3.64 & -0.58 & 0.30 & $135^{\star}$ & 7.85 & 4.75 & 16.12 & -1.10 & 3.00 \\
\hline Thailand & 1.63 & 0.68 & 0.60 & 132.00 & 6.78 & 4.25 & 21.51 & -0.06 & 1.50 \\
\hline Turkey & 13.68 & -0.21 & 1.40 & $112^{*}$ & 3.83 & 2.89 & 6.91 & -1.10 & 3.00 \\
\hline United Kingdom & 0.85 & 0.45 & 0.11 & 712.00 & 81.53 & 41.44 & 2.85 & 2.60 & 3.00 \\
\hline United States & 1.69 & 1.00 & 0.21 & 187.00 & 14.78 & 9.20 & -0.13 & 2.60 & 3.00 \\
\hline
\end{tabular}

1/ IMF, APD Database and International Financial Statistics

2/ As percent of gross domestic product.

3/ Lane, Philip R. and Gian Maria, Milesi-Ferretti (2005): "Financial Globalization and Exchange Rates", IMF Working Paper, WP 05/3 and IMF, World Economic Review.

Data for Malaysia, Chile, Russia, South Africa, Turkey, Brazil, and India are reported for the period 2000-05 and Belgium for 2002-05.

4/ IMF, APD Regional Economic Outlook database, International Financial Statistics and World Economic Review.

5/ CEIC Data Company Ltd.; and IMF, International Financial Statistics and World Economic Review.

$6 /$ Prof. Menzie David Chinn, University of Wisconsin. Data pertains to average for the period of 2000-05. Higher number indicates more openness.

7/ Abiad, Abdul; Enrica Detragiche and Thierry Tressel (2007): A New Database on Financial Reforms, preliminary draft, International Monetary Fund. Data corresponds to average for the period of 2000-05. Higher number indicates more openness. 


\section{Correlation between Volatility in Monetary Conditions and Financial Openness, 2000-06 1/}

\begin{tabular}{|c|c|c|c|c|c|}
\hline & $\begin{array}{c}\text { Gross Foreign Assets } \\
\text { and Liabilities 2/ }\end{array}$ & Gross Capital Flow 2/ & Capital Inflow 2/ & Chinn-Ito Index & Abiad, et al Index \\
\hline Volatility in $\mathrm{MCl}$ & -0.14 & -0.24 & -0.25 & -0.41 & 0.09 \\
\hline Comovement with U.S. MCI & 0.22 & 0.19 & 0.17 & 0.23 & -0.21 \\
\hline Volatility in Reserve Money/GDP & 0.17 & -0.02 & -0.06 & -0.01 & -0.15 \\
\hline
\end{tabular}

1/ Correlation coefficients are based on the cross-country average of each of the variables for the period of 2000-06. Exchange Market Pressure Index for Belgium and Euro Area are not calculated. Also, Chinn-Ito Index and Capital Flow Index for Euro Area are not calculated.

2/ As percent of gross domestic product.

\section{Correlation among Different Measures of Openness, 2000-06 1/}

\begin{tabular}{|c|c|c|c|c|c|}
\hline & $\begin{array}{c}\text { Gross Foreign Assets } \\
\text { and Liabilities 2/ }\end{array}$ & Gross Capital Flow & Capital Inflow 2/ & $\begin{array}{l}\text { Chinn-Ito Index } \\
\text { Index }\end{array}$ & $\begin{array}{l}\text { Abiad, et al } \\
\text { Index }\end{array}$ \\
\hline Gross Foreign Assets and Liabilities 2/ & 1.00 & 0.93 & 0.91 & 0.60 & 0.34 \\
\hline Gross Capital Flow 2/ & & 1.00 & 0.99 & 0.64 & 0.35 \\
\hline Capital Inflow 2/ & & & 1.00 & 0.63 & 0.35 \\
\hline Chinn-Ito Index & & & & 1.00 & 0.50 \\
\hline Abiad, et al Index & & & & & 1.00 \\
\hline
\end{tabular}

$1 /$ Correlation coefficients are based on the cross-country average of each of the variables for the period of 2000-06. Chinn-Ito Index and Capital Flow Index for Euro Area are not calculated.

2/ As percent of gross domestic product. 
Correlation among Different Measures of Volatility, 2000-06 1/

\begin{tabular}{lcccc}
\hline & $\begin{array}{c}\text { Volatility in Reserve } \\
\text { Money/GDP }\end{array}$ & $\begin{array}{c}\text { Exchange Market } \\
\text { Pressure Index }\end{array}$ & $\begin{array}{c}\text { Volatility in Monetary } \\
\text { Condition Index }\end{array}$ & $\begin{array}{c}\text { Comovement } \\
\text { with U.S. MCl }\end{array}$ \\
\hline Volatility in Reserve & 1.00 & -0.09 & 0.31 & 0.08 \\
Exchange Market & & 1.00 & -0.17 & 0.03 \\
Volatility in Monetary & & & 1.00 & -0.28 \\
Comovement with U.S. & & & & 1.00 \\
\hline
\end{tabular}

1/ Correlation coefficients are based on the cross-country average of each of the variables for the period of 2000-06. 


\section{Data Description}

The Chinn-Ito Index of Financial Openness: ${ }^{20}$

The index is the first standardized principal component of three binary variables, viz the presence of multiple exchange rates, restrictions on current account transactions and requirement of the surrender of export proceeds, and a five-year moving average of another binary variable representing restrictions on capital account transactions. A higher value indicates that a country is more open to cross-border capital transactions. The series has a mean zero by the nature of its construction. It is a de jure measure on financial openness as it quantifies the regulatory restrictions on capital account transactions.

The Abiad-Detragiache-Tressel Index: ${ }^{21}$

A new database is being constructed by the researchers in the International Monetary Fund to measure the extent of financial reforms covering 82 economies over the period of 1973-2002. Among the seven dimensions in which financial reforms is being measured, capital account restrictions is one of them. A set of coding rules were used to construct this series based on information on unification of the exchange rate system, existence of controls on capital inflows and existence of controls on capital outflows. A country is given a final score on a scale from zero to three, with higher score representing liberalization and lower score indicating highest degree of financial repression.

\footnotetext{
${ }^{20}$ Ito, Hiro, and Menzie Chinn (2007).

${ }^{21}$ Abiad, Abdul; Enrica Detragiache, and Thierry Tressel (2007).
} 


\section{REFERENCES}

Abiad, Abdul, Enrica Detragiache, and Thierry Tressel (2007), “A New Database on Financial Reforms,” (unpublished; Washington: International Monetary Fund).

Ariyoshi, Akira, and others, 2000, Capital Controls, Country Experiences with their Use and Liberalization, IMF Occasional Paper No. 190, (Washington : International Monetary Fund).

Cheong, Latifah, 2005. "Globalization and the Operation of Monetary Policy in Malaysia”, Globalization and Monetary Policy in Emerging Markets, BIS Papers No. 23.

Bernanke, B. S., 2007, “Globalization and Monetary Policy,” BIS Review No. 21 (Basel: Bank for International Settlements).

Cardarelli, R., S. Elekdag, and M. A. Kose, 2007, "Managing Large Capital Inflows,” Chapter 3, World Economic Outlook, October (Washington: International Monetary Fund).

Chinn M. and H. Ito, 2007, "Notes on the Calculation of the Chinn-Ito Financial Openness Variable," (unpublished; Wisconsin: University of Wisconsin).

Edison, H., R. Guimaraes-Filho, C. Kramer, and J. Miniane, 2007 "Sterilized Intervention in Emerging Asia: Is It Effective?,” Regional Economic Outlook Asia and Pacific, October (Washington: International Monetary Fund).

Gray, S., 2007, Liquidity Forecasting Handbook, (unpublished; Washington: Bank of England and International Monetary Fund).

Hawkins J., 2005, “Globalization and Monetary Operations in Emerging Economies," in BIS Papers No. 23, pp. 59-80 (Basel: Bank for International Settlements).

Hussain, A. M., A. Mody, and K. A. Rogoff, 2005, "Exchange rate Durability and Performance in Developing vs. Advanced Economies,” Journal of Monetary Economics, Vol. 52, pp. 35-64.

Kannan, R., S. Sanyal, and B. B. Bhoi, 2006, "Monetary Conditions Index for India," Reserve Bank of India Occasional Papers, Vol. 27, No. 3 (Mumbai: Reserve Bank of India).

Kramer, C., and R. Kohli, 2007 “How Financially Open is India?”, Indian Economy Review, forthcoming. 
Laurens, B.J., and others, 2005, Monetary Policy Implementation at Different Stages of Market Development, IMF Occasional Paper No. 244 (Washington: International Monetary Fund).

McCauley, Robert, 2006, Understanding Monetary Policy in Malaysia and Thailand: Objectives, Instruments and independence, BIS.

Mishkin, F. S., 2007, "Globalization, Macroeconomic Performance, and Monetary Policy,” speech (Washington: U.S. Federal Reserve System).

Otker-Robe, I., P. Zbigniew, T. Barry and D. Vavra, 2007, "Coping with Capital Inflows: Experiences of Selected European Countries,” IMF Working Paper 07/190, (Washington: International Monetary Fund).

Papademos, L., 2007, “The Effects of Globalization on Inflation, Liquidity, and Monetary Policy,” speech (Frankfurt: European Central Bank).

Pasricha, Gurnain, 2007, “Financial Integration in Emerging Market Economies,” Working Paper, Department of Economics, University of California, Santa Cruz.

Poirson, Helene, 2008, "Monetary Policy Communication and Transparency," Chapter III in India: Selected Issues, IMF Country Report 08/52 (Washington: International Monetary Fund).

Saggar, M., 2007, “India: Monetary Operations and Surplus Liquidity,” in Liquidity Forecasting Handbook, (unpublished; Washington: Bank of England and International Monetary Fund).

Sidaoui, J. J., 2005, "Policies for International Reserve Accumulation under a Floating Exchange Rate Regime: the Experience of Mexico," in BIS Papers No. 23, pp. 216-229 (Basel: Bank for International Settlements).

Stevens, G., 2006, “Capital Flows and Monetary Policy,” Remarks to Investor Insights: ANZ Asia Pacific 2006 Seminar Singapore 17 September 2006 (Sydney: Reserve Bank of Australia).

Weber, A., 2007, “Challenges Posed by Financial Globalization,” in BIS Review No. 31 (Basel: Bank for International Settlements).

Williams, M.V., 2005, “Foreign Exchange Reserves: How Much is Enough,” Speech (Nassau: Central Bank of the Bahamas). 